\title{
Review Article \\ The Protective Role of Antioxidants in the Defence against ROS/RNS-Mediated Environmental Pollution
}

\author{
Borut Poljšak and Rok Fink \\ Faculty of Health Sciences, University of Ljubljana, Zdravstvena pot 5, SI-1000 Ljubljana, Slovenia \\ Correspondence should be addressed to Rok Fink; rok.fink@zf.uni-lj.si
}

Received 21 April 2014; Revised 3 June 2014; Accepted 17 June 2014; Published 20 July 2014

Academic Editor: Felipe Dal-Pizzol

Copyright (C) 2014 B. Poljšak and R. Fink. This is an open access article distributed under the Creative Commons Attribution License, which permits unrestricted use, distribution, and reproduction in any medium, provided the original work is properly cited.

\begin{abstract}
Overproduction of reactive oxygen and nitrogen species can result from exposure to environmental pollutants, such as ionising and nonionising radiation, ultraviolet radiation, elevated concentrations of ozone, nitrogen oxides, sulphur dioxide, cigarette smoke, asbestos, particulate matter, pesticides, dioxins and furans, polycyclic aromatic hydrocarbons, and many other compounds present in the environment. It appears that increased oxidative/nitrosative stress is often neglected mechanism by which environmental pollutants affect human health. Oxidation of and oxidative damage to cellular components and biomolecules have been suggested to be involved in the aetiology of several chronic diseases, including cancer, cardiovascular disease, cataracts, age-related macular degeneration, and aging. Several studies have demonstrated that the human body can alleviate oxidative stress using exogenous antioxidants. However, not all dietary antioxidant supplements display protective effects, for example, $\beta$-carotene for lung cancer prevention in smokers or tocopherols for photooxidative stress. In this review, we explore the increases in oxidative stress caused by exposure to environmental pollutants and the protective effects of antioxidants.
\end{abstract}

\section{Introduction}

Many environmental pollutants are sources of several reactive species (RS). RS is a collective term that includes both oxygen radicals and other reactive oxygen and nitrogen species (ROS/RNS). Free radicals, important for living organisms, include hydroxyl $\left(\mathrm{OH}^{*}\right)$, superoxide $\left(\mathrm{O}_{2}{ }^{--}\right)$, nitric oxide $\left(\mathrm{NO}^{\circ}\right)$, thyl $\left(\mathrm{RS}^{*}\right)$, and peroxyl $\left(\mathrm{RO}_{2}{ }^{\circ}\right)$ radical. Peroxynitrite $\left(\mathrm{ONOO}^{-}\right)$, hypochlorous acid $(\mathrm{HOCl})$, hydrogen peroxide $\left(\mathrm{H}_{2} \mathrm{O}_{2}\right)$, singlet oxygen $\left({ }^{1} \mathrm{O}_{2}\right)$, and ozone $\left(\mathrm{O}_{3}\right)$ are not free radicals but can easily lead to free radical reactions in living organisms. The term reactive oxygen species (ROS) is often used to include not only free radicals but also the nonradicals (e.g., ${ }^{1} \mathrm{O}_{2}, \mathrm{ONOO}^{-}, \mathrm{H}_{2} \mathrm{O}_{2}, \mathrm{O}_{3}$ ) [1].

There is strong evidence that RS is involved in oxidative/ nitrosative stress $(\mathrm{O} / \mathrm{NS})$ as a common mechanism by which several environmental pollutants induce damage. Oxidative stress can be defined as an excessive amount of RS, which is the net result of an imbalance between production and destruction of RS (the latter is regulated by antioxidant defences).
Oxidative stress is a consequence of an increased generation of RS and/or reduced physiological activity of antioxidant defences against RS. Environmental pollutants stimulate a variety of mechanisms of toxicity on molecular level and oxidative stress seems to be the common denominator leading to the damage to cellular membrane lipids, DNA, and proteins [2], as well as modulation of antioxidant enzymes. RS are, due to their high reactivity (e.g., hydroxyl radical formation), prone to cause damage to any type of molecule within the cell, for example, polyunsaturated fatty acids, glutathione, certain amino acids, and so forth.

When the antioxidant defence in the human body becomes overwhelmed, oxidative stress to the cellular components often occurs, inducing inflammatory, adaptive, injurious, and reparative processes [3]. On other hand, lifestyle and nutrition might play an important role against environmental oxidant exposure and damage. Protection against O/NS-mediated environmental pollutants can generally occur at two levels: (i) physiochemical protection to lower the dose of exposure, which typically cannot be accomplished 
by individuals living in polluted areas, or (ii) physiological protection to increase the antioxidative defence of the organism. There is growing scientific evidence that low molecularweight antioxidants are involved in the prevention of or the decrease in the damage caused by certain environmental pollutants. Because we have little influence on the increasing levels of endogenous antioxidants, it would be reasonable to increase the amount of exogenous antioxidants (mainly through ingestion) to strengthen the defensive properties of organisms against environmental oxidative stress. The current evidence suggests that increased consumption of fruits and vegetables or certain dietary supplements can substantially enhance the protection against many common types of environmentally induced O/NS.

\section{Purpose}

This review aims to determine whether antioxidants can modulate the toxicity of environmental pollutants, thereby influencing health and disease outcome associated with oxidative stress-induced insults. Evidence will be presented that environmental pollution increases oxidative stress and that dietary supplementation with antioxidants may play a role on the neutralization or buffering of the effects of pollutants with oxidizing properties. The recommendation for the use of dietary antioxidants in areas of increased environmental pollution will be discussed.

This review summarises the most common and healthrelevant sources of oxidative stress like air pollution, radiation, pesticides, noise, and household chemicals. Due to space constrains and a broad scientific data, not all the studies could be covered in this review. The reader is thus referred to search through provided references (and references therein) for further details on selected environmental pollutant or selected antioxidant.

\subsection{Air Pollution-Induced Oxidative Stress and Protection} against It. The health effects of air pollution result from minor irritation of the eyes and the upper respiratory system to chronic respiratory disease, heart and vascular disease, lung cancer, and death. Different studies presented in Table 1 are demonstrating increased oxidative stress/damage due to air pollutant exposure and that antioxidants could offer certain level of protection [4-7].

Oxygen could be presented as the leading air pollutant in regard to oxidative stress formation. Molecular $\mathrm{O}_{2}$ itself qualifies as a free radical because it has two unpaired electrons with parallel spin in different $\pi$-antibonding orbitals. This spin restriction accounts for its relative stability and paramagnetic properties. $\mathrm{O}_{2}$ is capable of accepting electrons to its antibonding orbitals, becoming "reduced" in the process, and, therefore, functioning as a strong oxidizing agent [76]. The diatomic molecule of oxygen contains two uncoupled electrons and can therefore undergo reduction, yielding several different oxygen metabolites, which are collectively called ROS. Mitochondria are the main site of intracellular oxygen consumption and the main source of ROS formation $[8,10$, $13,77]$. Once ROS are produced, they are removed by cellular defenses which include the enzymes superoxide dismutase (Mn-SOD, Cu/Zn-SOD, and extracellular (EC)-SOD), catalase, glutathione peroxidase, peroxiredoxins, and the nonenzymatic antioxidants, like glutathione (GSH), thiore-doxin, ascorbate, $\alpha$-tocopherol, and uric acid $[9,78]$. Since oxidative damage of cells increases with age, the increased intake of exogenous antioxidants may support the endogenous antioxidative defense. Clinical studies imply that eating a diet rich in fruits, vegetables, whole grains, legumes, and omega-3 fatty acids can help humans in decreasing oxidative stress and postponing the incidence of degenerative diseases [79].

Ozone is formed from dioxygen by the action of ultraviolet light and atmospheric electrical discharges. Ozone is a very reactive gas whose uptake depends on the availability of antioxidants in the lining fluids $[17,18,52]$. The surface of the lung is covered with a thin layer of fluid that contains a range of antioxidants that appear to provide the first line of defence against air pollutants. Mudway et al. [17] studied the interaction of ozone with antioxidants and found that the hierarchy toward ozone in human epithelial lining fluid was ascorbic acid followed by uric acid and then glutathione. $\mathrm{Wu}$ and Meng [34] analysed the effects of sea buckthorn seed oil on the protection against sulphur dioxide inhalation. They found that buckthorn seed oil contributed antioxidant effects. Furthermore, study by Zhao et al. [33] revealed the protective effect of salicylic acid and vitamin $\mathrm{C}$ on sulphur dioxideinduced lipid peroxidation in mice.

Tobacco smoke is one of the most common air pollutants and generates high amounts of various ROS/RNS. Cigaretteinduced oxidative stress was found to be affected by the protective effects of vitamin C, glutathione, and other antioxidants, mainly as quenchers of ROS/RNS (Table 1) [36-41].

Kienast et al. [54] demonstrated that alveolar macrophages and peripheral blood mononuclear cells become activated following exposure to nitrogen dioxide. Several studies have demonstrated that certain antioxidants might play a beneficial role in $\mathrm{NO}_{x}$-induced toxicity. Guth and Mavis [55] and Sevanian et al. $[56,80]$ examined the effect of vitamin $\mathrm{E}$ content on the lungs. Furthermore, a study by Böhm et al. [62] revealed that dietary uptake of tomato lycopene protects human cells against nitrogen dioxide-mediated damage. The possible influence of dietary antioxidants, especially vitamin $\mathrm{C}$, on the increasing prevalence of asthma was explored by Hatch [81].

Particulate matter can also cause oxidative stress via direct generation of ROS from the surfaces of soluble compounds, altering the function of mitochondria or reducing the activity of nicotinamide adenine dinucleotide phosphateoxidase, inducing the activation of inflammatory cells to generate ROS and RNS and mediating oxidative DNA damage $[63,82]$. Antioxidants could also provide protection against particulate matter-induced toxicity. Indeed, lung lining fluid antioxidants (urate, glutathione, and ascorbate) were demonstrated to be effective in a study by Greenwell et al. [83]. Luo et al. [70] detected an inhibitory effect of green tea extract on the carcinogenesis induced by the combination of asbestos and benzo(a)pyrene in rats drinking $2 \%$ green tea extract throughout their lives. 
TABLE 1: Studies demonstrating increased oxidative stress/damage due to air pollutant exposure and the protective effects of antioxidants.

\begin{tabular}{|c|c|c|c|c|}
\hline Air pollutant & Increased oxidative stress markers & Study & $\begin{array}{l}\text { Antioxidants exerting a } \\
\text { protective effect }\end{array}$ & Study \\
\hline \multirow{3}{*}{ Oxygen $\left(\mathrm{O}_{2}\right)$} & $\begin{array}{l}\text { Superoxide and hydrogen } \\
\text { peroxide generation }\end{array}$ & Floyd (1995) [8] & $\begin{array}{l}\text { Catalases, glutathione } \\
\text { peroxidases, and } \\
\text { peroxiredoxins }\end{array}$ & $\begin{array}{l}\text { Nordberg and Arnér (2001) } \\
\text { [9] }\end{array}$ \\
\hline & Hydroxyl radical $\left(\mathrm{OH}^{*}\right)$ & $\begin{array}{l}\text { Forman and Boveris (1982) } \\
{[10]} \\
\text { Keyer and Imlay (1996) [11] } \\
\text { Hutchinson (1985) [12] } \\
\text { Ames (1983) [13] }\end{array}$ & & \\
\hline & Oxidative DNA lesions & $\begin{array}{l}\text { Friedberg et al. (1995) [14] } \\
\text { Speakman et al. (2003) [15] } \\
\text { Shackelford et al. (1999) } \\
{[16]}\end{array}$ & & \\
\hline \multirow{4}{*}{ Ozone $\left(\mathrm{O}_{3}\right)$} & Antioxidant depletion & $\begin{array}{l}\text { Mudway et al. (1996) [17] } \\
\text { Pryor (1992) [18] } \\
\text { Cross et al. (2002) [3] }\end{array}$ & $\begin{array}{l}\text { Vitamins } \mathrm{C} \text { and } \mathrm{E} \text { and } \\
\text { beta-carotene }\end{array}$ & $\begin{array}{l}\text { Grievink et al. (1999; 1997) } \\
{[19,20]} \\
\text { Samet et al. (2001) [21] } \\
\text { Menzel (1994) [22] } \\
\text { Romieu et al. (2002) [23] } \\
\text { Romieu et al. (1998) [24] }\end{array}$ \\
\hline & Protein oxidation & $\begin{array}{l}\text { Kelly and Mudway (2003) } \\
\text { [5] }\end{array}$ & & Grievink et al. (2000) [25] \\
\hline & Membrane oxidation & Ballinger et al. (2005) [26] & & \\
\hline & Inflammation & Menzel (1994) [22] & & \\
\hline \multirow{5}{*}{$\begin{array}{l}\text { Sulphur } \\
\text { dioxide }\left(\mathrm{SO}_{2}\right)\end{array}$} & TBARS & $\begin{array}{l}\text { Meng et al. (2003) [27] } \\
\text { Meng and Bai (2004) [28] }\end{array}$ & Vitamin E & $\begin{array}{l}\text { Ergonul et al. (2007) [29] } \\
\text { Etlik et al. (1997) [30] }\end{array}$ \\
\hline & & Zhao et al. (2009) [31] & Vitamin C & \\
\hline & $\begin{array}{l}\text { Depletion of endogenous } \\
\text { antioxidants }\end{array}$ & $\begin{array}{l}\text { Etlik et al. }(1997,1995) \\
{[30,32]} \\
\text { Zhao et al. (2008) [33] }\end{array}$ & Salicylic acid and vitamin $\mathrm{C}$ & Zhao et al. (2009) [31] \\
\hline & Malondialdehyde & Wu and Meng (2003) [34] & GSH & $\begin{array}{l}\text { Langley-Evans et al. (1996) } \\
\text { [35] }\end{array}$ \\
\hline & $\begin{array}{l}\text { Change in the glutathione redox } \\
\text { system }\end{array}$ & & Sea buckthorn seed oil & Wu and Meng (2003) [34] \\
\hline \multirow{8}{*}{$\begin{array}{l}\text { Cigarette } \\
\text { smoke }\end{array}$} & Decreased antioxidant capacity & $\begin{array}{l}\text { Midgette et al. (1993) [36] } \\
\text { Banerjee et al. (1998) [37] } \\
\text { Bloomer (2007) [38] } \\
\text { Aycicek et al. (2005) [39] } \\
\text { Tsuchiya et al. (2002) [40] } \\
\text { Zhou et al. (2000) [41] }\end{array}$ & Vitamin C & $\begin{array}{l}\text { Banerjee et al. (2008) [42] } \\
\text { Mayne and Cartmel (1999) } \\
{[43]}\end{array}$ \\
\hline & & & $\begin{array}{l}\text { Cruciferous vegetables and } \\
\text { green tea } \\
((-) \text {-epigallocatechin } \\
\text { gallate (EGCG) and } \\
\text { caffeine) }\end{array}$ & $\begin{array}{l}\text { Chung et al. (1993) [44] } \\
\text { Xu et al. (1992) [45] }\end{array}$ \\
\hline & Lipid peroxidation & $\begin{array}{l}\text { Banerjee et al. (1998) [37] } \\
\text { Jha et al. (2007) [46] }\end{array}$ & Black tea & Chung (1999) [47] \\
\hline & Oxidation of purines & Jha et al. (2007) [46] & \multirow{5}{*}{$\begin{array}{l}\text { Tomato-based juice, } \\
\text { vitamin E, and } \\
\text { beta-carotene }\end{array}$} & \multirow{5}{*}{$\begin{array}{l}\text { Mayne and Cartmel (1999) } \\
\text { [43] }\end{array}$} \\
\hline & 8-OH-dGuo & Xu et al. (1992) [45] & & \\
\hline & $\begin{array}{l}\text { Decreased antioxidant vitamin } \\
\text { activities }\end{array}$ & $\begin{array}{l}\text { Zhou et al. (1997) [48] } \\
\text { Dietrich et al. (2003) [49] } \\
\text { Chávez et al. (2007) [50] } \\
\text { Bloomer (2007) [38] }\end{array}$ & & \\
\hline & Protein damage and inflammation & Banerjee et al. (2008) [42] & & \\
\hline & Malondialdehyde (MDA) & $\begin{array}{l}\text { Chávez et al. (2007) [50] } \\
\text { Polidori et al. (2003) [51] }\end{array}$ & & \\
\hline
\end{tabular}


TABle 1: Continued.

\begin{tabular}{|c|c|c|c|c|}
\hline Air pollutant & Increased oxidative stress markers & Study & $\begin{array}{l}\text { Antioxidants exerting a } \\
\text { protective effect }\end{array}$ & Study \\
\hline \multirow{3}{*}{$\begin{array}{l}\text { Nitrogen } \\
\text { oxides }\left(\mathrm{NO}_{x}\right)\end{array}$} & $\begin{array}{l}\text { Aldehydes, hydrogen peroxide, } \\
\text { and reactive oxygen intermediates }\end{array}$ & $\begin{array}{l}\text { Pryor and Church (1991) } \\
\text { [52] } \\
\text { Last et al. (1994) [53] } \\
\text { Kienast et al. (1994) [54] }\end{array}$ & Vitamin E & $\begin{array}{l}\text { Guth and Mavis (1986) [55] } \\
\text { Sevanian et al. (1982) [56] }\end{array}$ \\
\hline & Depletion of antioxidants & $\begin{array}{l}\text { Kelly and Tetley (1997) [57] } \\
\text { Kelly et al. (1996) [58] }\end{array}$ & Vitamin C & $\begin{array}{l}\text { Rietjens et al. (1986) [59] } \\
\text { Mohsenin (1987) [60] }\end{array}$ \\
\hline & Lipid peroxidation & $\begin{array}{l}\text { Sevanian et al. (1982) [56] } \\
\text { Khopde et al. (1998) [61] }\end{array}$ & Lycopene & Böhm et al. (2001) [62] \\
\hline \multirow{5}{*}{$\begin{array}{l}\text { Particulate } \\
\text { matter (PM) }\end{array}$} & Direct generation of ROS & $\begin{array}{l}\text { González-Flecha (2004) } \\
\text { [63] }\end{array}$ & $\begin{array}{l}\mathrm{N} \text {-acetylcysteine and } \\
\text { deferoxamine }\end{array}$ & Pinho et al. (2005) [64] \\
\hline & $\begin{array}{l}\text { Proinflammatory mediators } \\
\text { released from PM-stimulated } \\
\text { macrophages }\end{array}$ & $\begin{array}{l}\text { González-Flecha (2004) } \\
\text { [63] }\end{array}$ & & \\
\hline & Oxidative DNA damage & $\begin{array}{l}\text { González-Flecha (2004) } \\
\text { [63] } \\
\text { Aganasur et al. (2001) [65] }\end{array}$ & & \\
\hline & $\begin{array}{l}\text { Inhibitory effects on oxidative } \\
\text { stress-related enzymes }\end{array}$ & Hatzis et al. (2006) [66] & & \\
\hline & $\begin{array}{l}\text { Thiobarbituric acid reactive } \\
\text { substances, protein carbonyls }\end{array}$ & Possamai et al. (2010) [67] & vitamins $\mathrm{C}$ and $\mathrm{E}$ & Possamai et al. (2010) [67] \\
\hline \multirow{5}{*}{ Asbestos } & $\begin{array}{l}\text { ROS formation (oxygen free } \\
\text { radicals) }\end{array}$ & $\begin{array}{l}\text { Kamp et al. (1992) [68] } \\
\text { Walker et al. (1992) [69] }\end{array}$ & Green tea extract & Luo et al. (1995) [70] \\
\hline & $\begin{array}{l}\text { Hydrogen peroxide, hydroxyl } \\
\text { radical, and superoxide anion }\end{array}$ & $\begin{array}{l}\text { Lewczuk and Owczarek } \\
\text { (1992) [71] }\end{array}$ & SOD & Fattman et al. (2006) [72] \\
\hline & Activation of phagocytic cells & $\begin{array}{l}\text { Kamp et al. (1992) [68] } \\
\text { Hei et al. (2006) [73] } \\
\text { Walker et al. (1992) [69] }\end{array}$ & & \\
\hline & Increased 8-isoprostane & Pelclová et al. (2008) [74] & & \\
\hline & 8-Hydroxy-2'-deoxyguanosine & $\begin{array}{l}\text { Marczynski et al. (2000) } \\
{[75]}\end{array}$ & & \\
\hline
\end{tabular}

As the diet is the main source of antioxidant micronutrients, a plausible link now exists between the exposure to air pollution and the quality of food consumed.

\subsection{Radiation-Induced Oxidative Stress and Protection against} It. Ionising radiation consists of highly energetic particles which can generate ROS. These ROS can either be generated primarily via radiolysis of water or they may be formed by secondary reactions. Extensive doses of ionizing radiation have been shown to have a mutating effect; for example, Sperati et al. [84] concluded that indoor radioactivity appears to affect the urinary excretion of $8-\mathrm{OHdG}$ among females, who are estimated to exhibit a higher occupancy in the dwellings measured than males (Table 2). Many compounds have been demonstrated to protect against cell injury caused by radiation-induced ROS formation. One of these compounds is ebselen, a selenoorganic compound [85]. Another compound is $\mathrm{N}$-acetylcysteine, which reduces nitrosative damage during radiotherapy [86] as well as oxidative damage [87]. The radioprotective effects of quercetin and the ethanolic extract of propolis in gamma-irradiated mice were also detected [88]. The radioprotective and radiosensitising activities of curcumin were demonstrated in a study by Jagetia [89].

Aside from ionising radiation, nonionising radiation also causes oxidative stress. Magnetic fields can affect biological systems by increasing the release of free radicals. There are several studies that indicate a relationship between electromagnetic fields, ROS levels, and OS to exert toxic effects on living organisms [90]. Because it is unlikely that electromagnetic fields can induce DNA damage directly due to their low energy levels, most studies have examined their effects on the cell membrane, general and specific gene expression levels, and signal transduction pathways [91]. Musaev et al. [92] indicated that decimetric microwaves exert oxidant effects at a high intensity of irradiation (specific absorption rate of $15 \mathrm{~mW} / \mathrm{kg}$ ) and antioxidant effects at a low intensity (specific absorption rate of $5 \mathrm{~mW} / \mathrm{kg}$ ) (Table 2). The protective effects of melatonin and caffeic acid phenethyl ester against retinal oxidative stress during the long-term use of mobile phones were reported [93]. Jajte et al. [94] concluded that melatonin provides protection against DNA damage to rat lymphocytes. Another investigation revealed that Ginkgo biloba prevents mobile phone-induced oxidative stress [95]. Guney et al. [96] found that vitamins $\mathrm{E}$ and $\mathrm{C}$ reduce phone-induced endometrial damage.

Visible and UV light are insufficient to ionize most biomolecules. Nevertheless, human exposure to ultraviolet radiation has important public health implications. Although the skin possesses extremely efficient antioxidant activities, during aging, the ROS levels rise and the antioxidant activities decline. In addition, UV exposure to the skin results in 


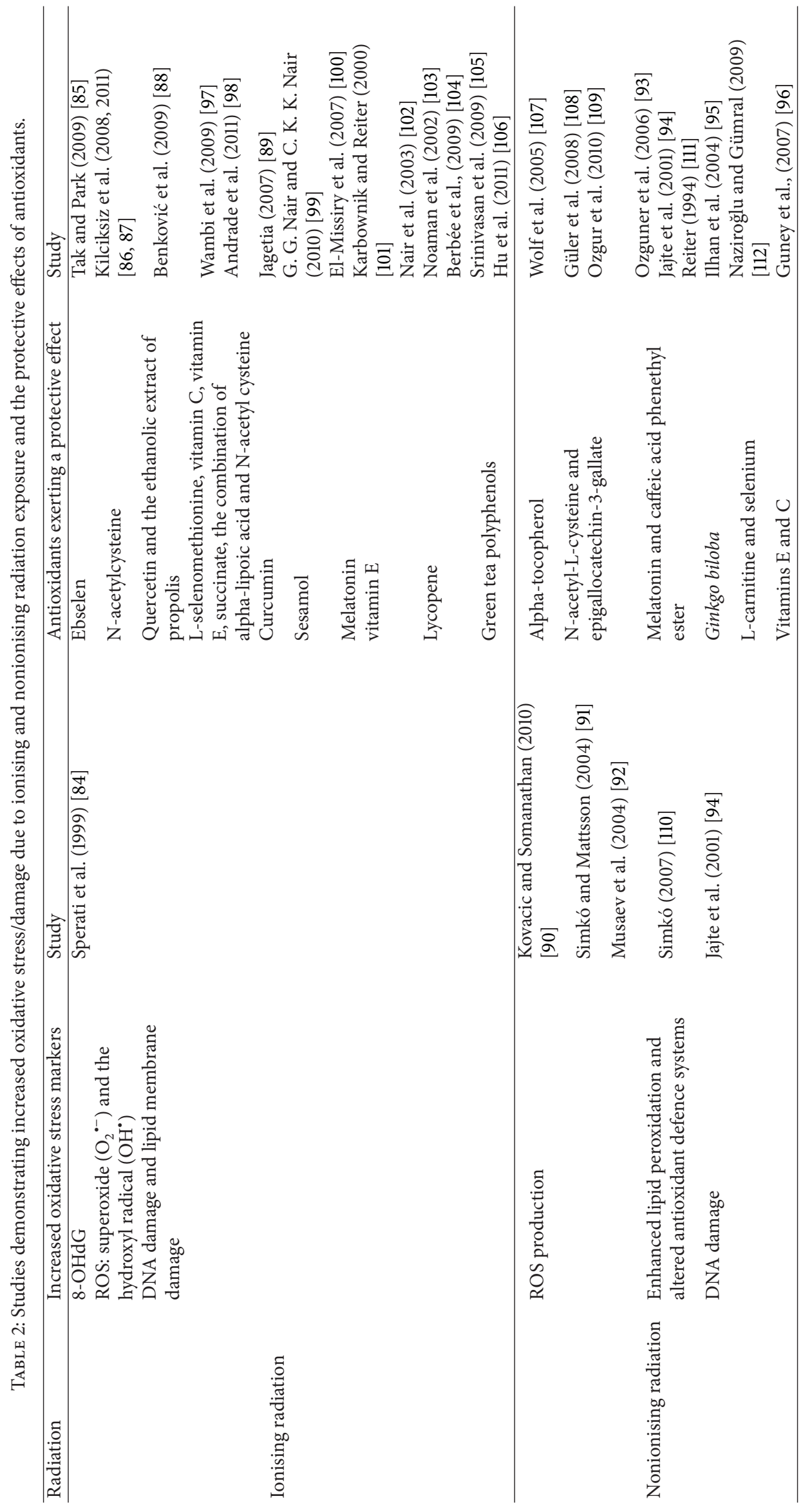




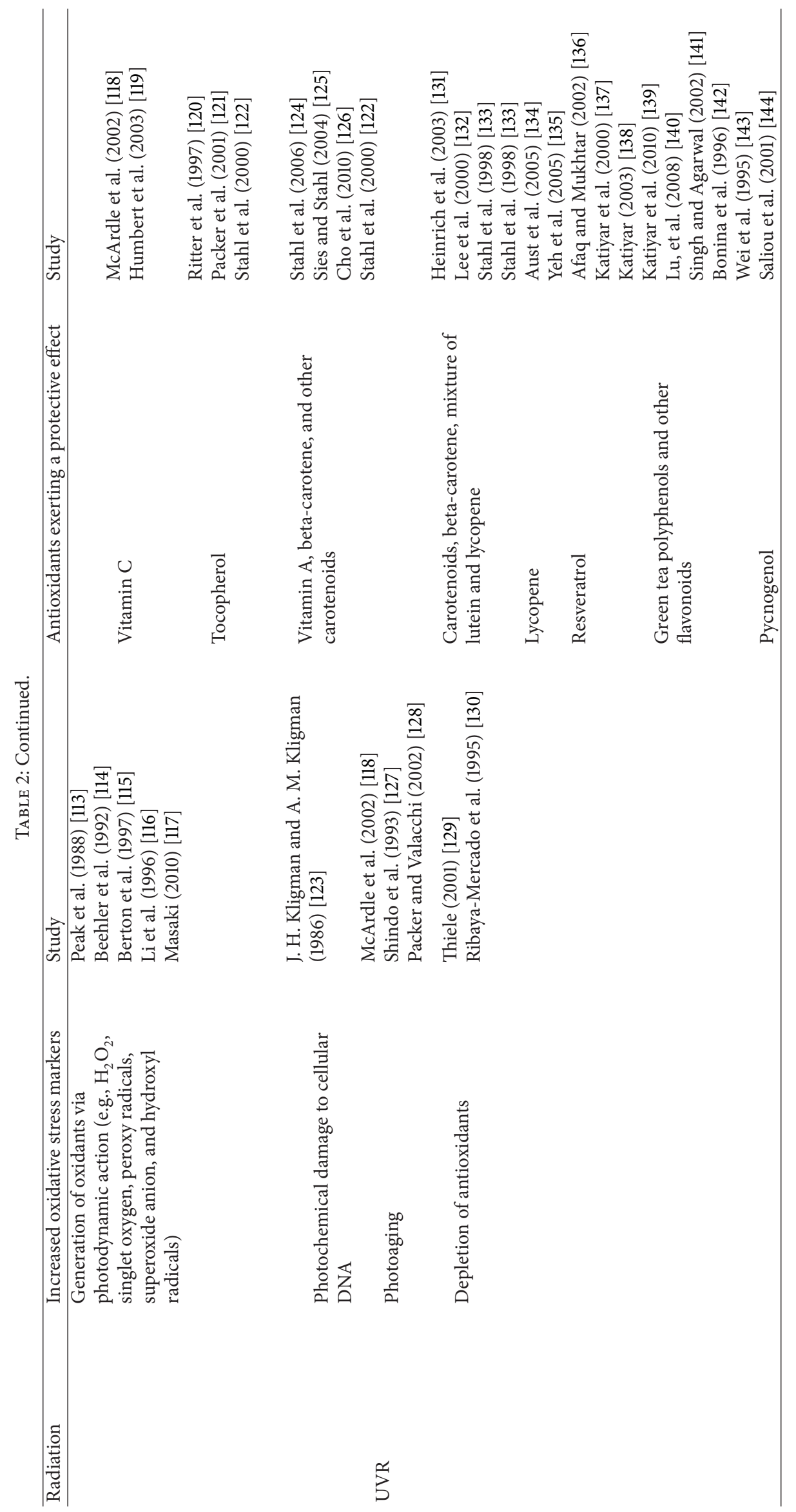


the generation of ROS [118], such as singlet oxygen, peroxy radicals, the superoxide anion, and hydroxyl radicals, which damage DNA and non-DNA cellular targets [113-116] and accelerate the skin aging process. UV-radiation alters endogenous antioxidant protection; for example, in a study by Shindo et al. [127], after UV-irradiation, the epidermal and dermal catalase and superoxide dismutase activities were greatly decreased. With respect to the protective role of antioxidants, many studies (Table 2) investigated the effect of vitamin C on ultraviolet-radiation- (UVR-) induced damage. Oral vitamin C supplements resulted in significant increases in plasma and skin vitamin C content [118]. In the study by Aust et al. [134], the photoprotective effects of synthetic lycopene after 12 weeks of supplementation were examined, and significant increases in the lycopene serum and total skin carotenoid levels were detected. Studies of animals and humans suggested that green tea polyphenols are photoprotective and can be administered to prevent solar UVB lightinduced skin disorders [137]. A review of the research reveals that polyphenols or other phytochemicals, such as green tea polyphenols, grape seed proanthocyanidins, resveratrol, silymarin, genistein, and others, exert substantial photoprotective effects against UV-induced skin inflammation, oxidative stress, DNA damage, and so forth.

Presently, we are exposed to various sources of radiation, both ionising and nonionising. The results of many studies indicate that the human body can cope with radiationinduced oxidative stress to a certain degree by consuming an appropriate antioxidant diet.

2.3. Pesticide-Induced Oxidative Stress and Protection against It. Pesticides have become an integral constituent of the ecosystem due to their widespread use, distribution, and the stability of some of the pesticides in the environment. Pesticide exposure may play a major role in increased oxidative stress of the organisms and may result in altered disease susceptibility. Bagchi et al. [145] demonstrated that pesticides induce the production of ROS and oxidative damage to tissues. de Liz Oliveira Cavalli [146] found that exposure to glyphosate causes oxidative stress and activates multiple stress-response pathways leading to Sertoli cell death in prepubertal rat testis. The role of oxidative stress in immune cell toxicity induced by the pesticides lindane, malathion, and permethrin was examined by Olgun and Misra [147]. Hassoun et al. [148] reported that chlordane produces oxidative tissue damage based on the levels of hepatic lipid peroxidation and DNA damage (Table 3). Bus et al. [149] reported that paraquat pulmonary toxicity results from the cyclic reduction and oxidation of paraquat. The results of a study performed by Pérez-Maldonado et al. [150] demonstrated the induction of apoptosis by DDT. Hassoun et al. [148] reported that lindane, DDT, chlordane, and endrin exposure resulted in significant increases in hepatic lipid peroxidation and DNA damage. Another study by Senft et al. [151] found out that dioxin increases mitochondrial respiration-dependent ROS production. On the other hand, Ciftci et al. [152] reported a protective effect of curcumin on the immune system of rats intoxicated with 2,3,7,8-tetrachlorodibenzo-p-dioxin. Additionally, Hung et al. [153] suggested that tea melanin might be a potential agent against the development of tetrachlorodibenzodioxininduced oxidative stress. Gultekin et al. [154] examined the effects of melatonin and vitamins $\mathrm{E}$ and $\mathrm{C}$ on the reduction of chlorpyrifos-ethyl.

Another group of pesticides are polychlorinated biphenyls (PCBs), which also induce increased intracellular ROS production. Zhu et al. [155] indicated that different PCB compounds (Aroclor 1254, PCB153, and the 2-(4-chlorophenyl)1,4-benzoquinone metabolite of PCB3) increase the steadystate levels of intracellular $\mathrm{O}_{2}{ }^{--}$and $\mathrm{H}_{2} \mathrm{O}_{2}$ in breast and prostate epithelial cells. Many antioxidants showed protection also against PCB-induced oxidative stress and damage. Ramadass et al. [156] tested the hypothesis that flavonoids modify PCB-mediated cytotoxicity and found that flavonoids inhibit PCB-induced oxidative stress. Zhu et al. [155] demonstrated that treatment with $\mathrm{N}$-acetylcysteine significantly protected cells against PCB-mediated toxicity. Red ginseng, which displays a variety of biological and pharmacological activities, including antioxidant, anti-inflammatory, antimutagenic, and anticarcinogenic effects, was found to protect the body against oxidative stress/damage induced by PCB exposure [157]. Sridevi et al. [158] also reported that the effect of alpha-tocopherol against PCB-induced neurotoxicity resulted in decreased oxidative stress. Another study reported the synergistic effects of vitamins $\mathrm{C}$ and $\mathrm{E}$ against PCB(Aroclor 1254) induced oxidative damage [159].

Dioxins and furans are byproducts of chemicals production. Dioxins may be released into the environment through the production of pesticides and other chlorinated substances. Both dioxins and furans are related to a variety of incineration reactions and the use of a variety of chemical products. Ciftci and coworkers reported that dioxin (2,3,7,8tetrachlorodibenzo-p-dioxin; TCDD) causes an oxidative stress response in the rats liver. The subcellular sources and underlying mechanisms of dioxin-induced reactive oxygen species, however, are not well understood. TCDD increases the formation of thiobarbituric acid-reactive substances. It also causes a significant decline in the levels of glutathione, catalase, GSH-Px, and $\mathrm{Cu}-\mathrm{Zn}$ superoxide dismutase in rats [160]. The impact of 2-furan-2-yl-1H-benzimidazole on vitamins A, E, C, and Se, malondialdehyde, and glutathione peroxidase levels on rats was analysed in a study by Karatas et al. [161]. The results showed that vitamins A, E, C, and Se levels were lower than the control groups, while serum MDA level and GSH-Px activity flexibly increased, depending on the injection days. The observed decreases in vitamins A, E, C, and Se levels in the blood might be causally related to the increased amount of ROS. The potential protective effect of quercetin on TCDD induced testicular damage in rats was studied by Ciftci et al. [160]. The results showed that exposure to TCDD induces testicular damage, and quercetin prevents TCDD-induced testicular damage in rats. Resveratrol's antioxidative effects were also investigated against in a study by Ishida et al. [162]. The results suggested that oral resveratrol is an attractive candidate for combating dioxin toxicity. Türkez et al. [163] analysed effects of propolis against TCDD induced hepatotoxicity in rats and found that propolis 
TABLE 3: Studies demonstrating increased oxidative stress/damage due to pesticide exposure and the protective effects of antioxidants.

\begin{tabular}{|c|c|c|c|c|}
\hline Pesticide & $\begin{array}{l}\text { Increased oxidative stress } \\
\text { markers }\end{array}$ & Study & $\begin{array}{l}\text { Antioxidants exerting a } \\
\text { protective effect }\end{array}$ & Study \\
\hline \multirow{5}{*}{ General } & ROS & $\begin{array}{l}\text { Bagchi et al. (1995) [145] } \\
\text { Song et al. (2007) [164] } \\
\text { Olgun and Misra (2006) [147] }\end{array}$ & & \\
\hline & DNA damage & $\begin{array}{l}\text { Bagchi et al. }(1995,1996) \\
{[145,165]} \\
\text { Kisby et al. (2009) }[166]\end{array}$ & & \\
\hline & $\begin{array}{l}\text { Alterations in antioxidant } \\
\text { enzymes and the glutathione } \\
\text { redox system }\end{array}$ & Yi et al. (2007) [167] & & \\
\hline & $\begin{array}{l}\text { Increased level of } \\
\text { malondialdehyde }\end{array}$ & $\begin{array}{l}\text { Kesavachandran et al. (2006) } \\
{[168]}\end{array}$ & & \\
\hline & Lipid peroxidation & Hassoun et al. (1993) [148] & & \\
\hline \multirow{3}{*}{$\begin{array}{l}\text { Bipyridylium } \\
\text { herbicides } \\
\text { (paraquat, diquat } \\
\text { and difenzoquat) }\end{array}$} & $\begin{array}{l}\text { Production of superoxide anions } \\
\text { and singlet oxygen }\end{array}$ & Bus et al. (1976) [149] & Selenium & $\begin{array}{l}\text { Combs and Peterson (1983) } \\
{[169]} \\
\text { Glass et al. (1985) [170] } \\
\text { Cheng et al. (1998) [171] }\end{array}$ \\
\hline & $\begin{array}{l}\text { Lipid peroxidation (peroxidation } \\
\text { of cellular membranes) }\end{array}$ & Bus et al. (1976) [149] & & \\
\hline & $\begin{array}{l}\text { Alterations in antioxidant } \\
\text { enzymes and the glutathione } \\
\text { redox system }\end{array}$ & Takizawa et al. (2007) [172] & $\begin{array}{l}\text { Glutathione reductase } \\
\text { and superoxide } \\
\text { dismutase }\end{array}$ & Aono et al. (1995) [173] \\
\hline \multirow{4}{*}{$\begin{array}{l}\text { Organo- } \\
\text { phosphate } \\
\text { insecticides }\end{array}$} & Lipid peroxidation & $\begin{array}{l}\text { Gultekin et al. (2001) [154] } \\
\text { Akturk et al. (2006) [174] } \\
\text { Hassoun et al. (1993) [148] }\end{array}$ & $\begin{array}{l}\text { Melatonin, vitamin } \mathrm{C} \\
\text { and vitamin } \mathrm{E}\end{array}$ & Gultekin et al. (2001) [154] \\
\hline & Decreased antioxidant defence & $\begin{array}{l}\text { Gultekin et al. (2001) [154] } \\
\text { Verma et al. (2007) [175] } \\
\text { Akturk et al. (2006) [174] }\end{array}$ & Vitamins A, E, and C & $\begin{array}{l}\text { Verma et al. (2007) [175] } \\
\text { Altunas et al. (2002) [176] } \\
\text { Akturk et al. (2006) [174] }\end{array}$ \\
\hline & Increased ROS production & Bagchi et al. (1995) [145] & & \\
\hline & DNA damage & Bagchi et al. (1995) [145] & Zinc & Goel et al. (2005) [177] \\
\hline \multirow{4}{*}{$\begin{array}{l}\text { Aldrin and } \\
\text { dieldrin }\end{array}$} & ROS production & Stevenson et al. (1999) [178] & $\begin{array}{l}\text { Alpha-tocopherol and } \\
\text { ascorbic acid }\end{array}$ & $\begin{array}{l}\text { Bachowski et al. (1998) } \\
{[179]} \\
\text { Stevenson et al. (1995) [180] }\end{array}$ \\
\hline & $\begin{array}{l}\text { Depletion of the antioxidant } \\
\text { defence }\end{array}$ & Klaunig et al. (1995) [181] & & \\
\hline & Lipid peroxidation & $\begin{array}{l}\text { Bachowski et al. (1998) [179] } \\
\text { Klaunig et al. (1995) [181] }\end{array}$ & & \\
\hline & DNA damage & Klaunig et al. (1995) [181] & & \\
\hline \multirow{3}{*}{ DDT } & ROS production & $\begin{array}{l}\text { Pérez-Maldonado et al. (2005) } \\
{[150]}\end{array}$ & N-acetyl-L-cysteine & $\begin{array}{l}\text { Pérez-Maldonado et al. } \\
\text { (2005) [150] }\end{array}$ \\
\hline & Lipid peroxidation & Hassoun et al. (1993) [148] & & \\
\hline & DNA damage & Hassoun et al. (1993) [148] & & \\
\hline \multirow{8}{*}{$\begin{array}{l}\text { Polychlorinated } \\
\text { dibenzo-para- } \\
\text { dioxins (dioxins) } \\
\text { and } \\
\text { polychlorinated } \\
\text { dibenzo furans } \\
\text { (furans) }\end{array}$} & $\begin{array}{l}\text { Depletion of the antioxidant } \\
\text { defence }\end{array}$ & $\begin{array}{l}\text { Ciftci et al. (2011) [160] } \\
\text { Stohs (1990) [182] } \\
\text { Karatas et al. (2008) [161] }\end{array}$ & Quercetin & Ciftci et al. (2011) [160] \\
\hline & Lipid peroxidation & $\begin{array}{l}\text { Stohs (1990) [182] } \\
\text { Karatas et al. (2008) [161] }\end{array}$ & $\begin{array}{l}\text { Curcumin, } \beta \text {-myrcene } \\
\text { and } 1,8 \text {-cineole }\end{array}$ & $\begin{array}{l}\text { Ciftci et al. (2011) [160] } \\
\text { Ciftci et al. (2010) [152] }\end{array}$ \\
\hline & & & Resveratrol & Ishida et al. (2009) [162] \\
\hline & & & Tea melanin & Hung et al. (2006) [153] \\
\hline & TBARS & Ciftci et al. (2011) [160] & Vitamin A and vitamin $\mathrm{E}$ & $\begin{array}{l}\text { Alsharif and Hassoun } \\
(2004)[183]\end{array}$ \\
\hline & Increased ROS production & Senft et al. (2002) [151] & & \\
\hline & $8-\mathrm{OHdG}$ & Wen et al. (2008) [184] & & \\
\hline & DNA damage & Stohs (1990) [182] & & \\
\hline
\end{tabular}


TABLe 3: Continued.

\begin{tabular}{|c|c|c|c|c|}
\hline Pesticide & $\begin{array}{l}\text { Increased oxidative stress } \\
\text { markers }\end{array}$ & Study & $\begin{array}{l}\text { Antioxidants exerting a } \\
\text { protective effect }\end{array}$ & Study \\
\hline \multirow{7}{*}{$\begin{array}{l}\text { Polychlorinated } \\
\text { biphenyls (PCBs) }\end{array}$} & $\begin{array}{l}\text { ROS production (superoxide and } \\
\text { hydrogen peroxide) }\end{array}$ & $\begin{array}{l}\text { Song et al. (2008) [185] } \\
\text { Zhu et al. (2009) [155] }\end{array}$ & $\begin{array}{l}\text { Dietary flavonoids } \\
\text { (epigallocatechin-3- } \\
\text { gallate (EGCG) and } \\
\text { quercetin) }\end{array}$ & Ramadass et al. (2003) [156] \\
\hline & $\begin{array}{l}\text { Imbalance in the antioxidant } \\
\text { status }\end{array}$ & $\begin{array}{l}\text { Zhu et al. (2009) [155] } \\
\text { Shimizu et al. (2007b) [186] }\end{array}$ & $\begin{array}{l}\mathrm{N} \text {-acetylcysteine (NAC) } \\
\text { and the combination of } \\
\text { polyethylene glycol } \\
\text { (PEG)-conjugated } \\
\mathrm{Cu} / \mathrm{Zn} \text {-SOD and } \\
\text { PEG-conjugated catalase }\end{array}$ & Zhu et al. (2009) [155] \\
\hline & Lipid peroxidation & Shimizu et al., (2007a) [187] & Red ginseng & Park et al. (2010) [157] \\
\hline & & & Alpha-tocopherol & $\begin{array}{l}\text { Banudevi et al. (2006) [188] } \\
\text { Sridevi et al. (2007) [158] }\end{array}$ \\
\hline & & & $\begin{array}{l}\text { Alpha-tocopherol and } \\
\text { ascorbic acid }\end{array}$ & $\begin{array}{l}\text { Krishnamoorthy et al. } \\
(2007) \text { [189] } \\
\text { Murugesan et al. (2005) } \\
\text { [159] } \\
\text { Zhou and Zhang (2005) } \\
{[190]}\end{array}$ \\
\hline & & & Melatonin & $\begin{array}{l}\text { Venkataraman et al. (2008) } \\
\text { [191] }\end{array}$ \\
\hline & & & Lycopene & Elumalai et al. (2009) [192] \\
\hline
\end{tabular}

alleviate pathological effects and prevents the suppression of antioxidant enzymes in the livers.

It can be concluded that the stimulation of ROS production, the induction of lipid peroxidation and oxidative DNA and protein damage, and the disturbance of the total antioxidant capacity of the body are mechanisms of the toxicity induced by most pesticides, including organophosphates, bipyridyl herbicides, and organochlorines. Antioxidant nutrients and related bioactive compounds common in fruits and vegetables as well as food additives can protect against environmental exposure to pesticides-induced oxidative stress/damage (Table 3).

\subsection{Household Chemical-Induced Oxidative Stress and Protec-} tion against It. The predominant use of industrial resins, such as urea-formaldehyde, phenol-formaldehyde, polyacetal, and melamine-formaldehyde resins, can be found in domestic environments in adhesives and binders for wood products, pulp products, paper products, plastics, synthetic fibres, and in textile finishing. Formaldehyde was demonstrated to exert increased oxidative stress formation (Table 4), primarily as lipid peroxidation, as found in a study performed by Chang and $\mathrm{Xu}$ [193]. Also in the case of household chemical-induced oxidative stress certain antioxidants showed protection. In a recent study, Köse et al. [194] reported that rose oil inhalation protects against formaldehyde-induced testicular damage in rats. Zararsiz et al. [195] demonstrated that exposure to formaldehyde increased the free radical levels in rats and that omega-3 fatty acids prevented this oxidative stress. The protective effect of melatonin against formaldehyde-induced renal oxidative damage in rats has also been reported [196].
Many studies have been performed on carbon tetrachloride because it is a well-known model of inducing chemical hepatic injury in mice. Also carbon tetrachloride exposure increases oxidative stress/damage in tested model organisms and carbon tetrachloride-induced damage has been reversed by many antioxidants examined. Thus, the antioxidant and hepatoprotective effects of many antioxidants and plant extracts against oxidative stress induced by carbon tetrachloride have been reported [198]. For example, chlorellamediated protection against carbon tetrachloride-induced oxidative damage in rats was demonstrated in a study by Peng et al. [224]. Ozturk et al. [201] found that apricot (Prunus armeniaca L) feeding exerted beneficial effects. The potency of vitamin $\mathrm{E}$ to enhance the recovery from carbon tetrachloride-induced renal oxidative damage in mice was revealed in a study by Adaramoye [202]. The protective effects of Curcuma longa Linnwere reported by Lee et al. [205]. The protective effect of blackberry extract against oxidative stress in carbon tetrachloride-treated rats was reported by Cho et al. [207].

Chemicals found in common household and personal care goods are major sources of oxidant exposure that can lead to oxidative stress. Many antioxidants, such as melatonin, vitamin E, ascorbate, and extracts from various plants, for example, rose, green tea, and blackberry, were reported to decrease oxidative stress and/or damage in vivo and in vitro.

2.5. Disinfection Byproducts (DBP) and Other Water Born Pollutants. The beneficial role of water ingestion can be minimised due to the formation of disinfection byproducts. Chlorination and ozonation in the water treatment process 
TABLE 4: Studies demonstrating increased oxidative stress/damage due to exposure to selected toxic compounds and the protective effects of antioxidants.

\begin{tabular}{|c|c|c|c|c|}
\hline Other & $\begin{array}{l}\text { Increased oxidative stress } \\
\text { markers }\end{array}$ & Study & $\begin{array}{l}\text { Antioxidants exerting a } \\
\text { protective effect }\end{array}$ & Study \\
\hline \multirow[b]{2}{*}{ Formaldehyde } & Lipid peroxidation & Chang and Xu (2006) [193] & Rose oil & Köse et al. (2011) [194] \\
\hline & $\begin{array}{l}\text { Imbalance in antioxidant } \\
\text { status }\end{array}$ & Chang and Xu (2006) [193] & Melatonin & Zararsiz et al. (2007) [196] \\
\hline \multirow{11}{*}{$\begin{array}{l}\text { Carbon } \\
\text { tetrachloride } \\
\left(\mathrm{CCl}_{4}\right)\end{array}$} & Increased ROS production & Brent and Rumack (1993) [197] & Electrolysed reduced water & Tsai et al. (2009) [198] \\
\hline & Lipid peroxidation & $\begin{array}{l}\text { Morrow et al. (1992) [199] } \\
\text { Basu (2003) [200] }\end{array}$ & $\begin{array}{l}\text { Apricot } \\
\text { (Prunus armeniaca L.) }\end{array}$ & Ozturk et al. (2009) [201] \\
\hline & & & Vitamin E & Adaramoye (2009) [202] \\
\hline & & & $\begin{array}{l}\text { Megahydrate silica hydride } \\
\text { Lutein }\end{array}$ & $\begin{array}{l}\text { Hsu et al. (2010) [203] } \\
\text { Sindhu et al. (2010) [204] }\end{array}$ \\
\hline & & & Curcuma longa & Lee et al. (2010) [205] \\
\hline & & & Acetyl-L-carnitine & $\begin{array}{l}\text { Annadurai et al. (2011) } \\
\text { [206] }\end{array}$ \\
\hline & & & Blackberry extract & Cho et al., (2011) [207] \\
\hline & & & Capsaicin & Hassan et al. (2012) [208] \\
\hline & & & Propolis & Bhadauria (2012) [209] \\
\hline & & & Melatonin and pinoline & Aranda et al. (2010) [210] \\
\hline & & & Black and green tea & Almurshed (2006) [211] \\
\hline \multirow{11}{*}{$\begin{array}{l}\text { Water disinfection } \\
\text { byproducts }\end{array}$} & $\begin{array}{l}\text { ROS production } \\
\left(\mathrm{OH}^{\circ}, \mathrm{H}_{2} \mathrm{O}_{2} \text {, and singlet }\right. \\
\left.\mathrm{O}_{2}\right)\end{array}$ & Hassoun and Ray (2003) [212] & $\begin{array}{l}\text { Ascorbate, glutathione, and } \\
\text { urate }\end{array}$ & Yadav et al. (2010) [213] \\
\hline & & & $\begin{array}{l}\text { Ascorbate and desferal } \\
\mathrm{N} \text {-acetyl-cysteine }\end{array}$ & $\begin{array}{l}\text { Yadav et al. (2010) [213] } \\
\text { Leustik et al. (2008) [214] }\end{array}$ \\
\hline & & & Ascorbate and deferoxamine & $\begin{array}{l}\text { Zarogiannis et al. (2011) } \\
\text { [215] }\end{array}$ \\
\hline & & & Green tea catechins & Kawai et al. (2008) [216] \\
\hline & & & Melatonin & Tan et al. (2000) [217] \\
\hline & & & S-allylcysteine & $\begin{array}{l}\text { Medina-Campos et al. } \\
(2007)[218]\end{array}$ \\
\hline & & & $\begin{array}{l}\text { Thioallyl compounds from } \\
\text { garlic }\end{array}$ & $\begin{array}{l}\text { Argüello-García et al. } \\
\text { (2010) [219] }\end{array}$ \\
\hline & & & Trolox & Strosova et al. (2009) [220] \\
\hline & & & Vitamin C & Carr et al. (2000) [221] \\
\hline & & & Glutathione & Rezk et al. (2004) [222] \\
\hline & & & $\begin{array}{l}\text { Many other local } \\
\text { Mediterranean plant foods }\end{array}$ & Schaffer et al. (2004) [223] \\
\hline
\end{tabular}

are believed to produce various active oxygen species, which seem to participate in the reaction with fumic acid, pollutants, and bacteria (Table 4). Hypochlorous acid ( $\mathrm{HOCl}$ ) is formed when $\mathrm{Cl}_{2}$ is added to the water for disinfection purposes. This acid is highly reactive and is capable of oxidising many biological molecules. $\mathrm{HOCl}$ reacts with $\mathrm{O}_{2}{ }^{-}$to give $\mathrm{OH}^{\bullet}$ and with $\mathrm{H}_{2} \mathrm{O}_{2}$ to form singlet $\mathrm{O}_{2}$. $\mathrm{HOCl}$ affects endogenous enzymatic antioxidants and increases oxidative stress. For example, Hassoun and Ray [212] demonstrated the induction of oxidative stress and cellular death of drinking water disinfection byproducts. Similar observations were reported by Leustik et al. [214]. Studies suggest that $\mathrm{Cl}_{2}$ inhalation damages both airway and alveolar epithelial tissues and that these damaging effects were ameliorated by the prophylactic administration of low molecular-weight antioxidants. Trolox was reported to be protective against oxidative injury induced by $\mathrm{HOCl}$ to $\mathrm{Ca}$-ATPase in the sarcoplasmic reticulum of skeletal muscle [220]. Ascorbic acid might also play a protective role (Table 4), especially in individuals consuming supplements containing this vitamin. Also thioallyl and Sallylcysteine (both are garlic-derived compounds), melatonine, glutathione, glutathione disulfide, S-methylglutathione, lipoic acid, and dihydrolipoic acid were reported to protect against hypochlorous acid and peroxynitrite-induced damage $[217-219,222])$.

Additionally, the following plant extracts display a protective effect against $\mathrm{HOCl}$-induced oxidative damage: Agaricus campestris, Cynara cardunculus, Thymus pulegioides, and Vicia faba [223]. When resolving the problem of DBP, first the cause of their formation should be assessed with different 
engineering approaches DBP, for example, by moving the point of chlorination downstream in the treatment train, reducing the natural organic matter precursor concentration, replacing prechlorination by peroxidation, and so forth.

The use of antioxidants as compounds which ameliorate DBP-induced toxicity should be just the last alternative when all other approaches deal with the DBP formation in the drinking water fail.

Researches in the past two decades have pointed out that redox active metals like iron $(\mathrm{Fe})$, copper $(\mathrm{Cu})$, chromium $(\mathrm{Cr})$, cobalt $(\mathrm{Co})$, and other metals present in water possess the ability to produce ROS such as superoxide anion radical and nitric oxide. Disruption of metal ion homeostasis may lead to oxidative stress, a state where increased formation of reactive oxygen species overwhelms body antioxidant protection and subsequently induces DNA damage, lipid peroxidation, protein modification, and other effects [225]. Pollutants in water like heavy metals $\mathrm{As}, \mathrm{Cd}, \mathrm{Cu}, \mathrm{Fe}$, $\mathrm{Pb}$, and $\mathrm{Zn}$ can cause oxidative stress in fish [226]. On other hand Yang and coworkers [227] reports that water spinach containing chlorophyll and lycopene have potential to reduce cytotoxicity and oxidative stress in liver induced by heavy metals. Besides heavy metals also pesticides in water can represent sources of oxidative stress. Atrazine and chlorpyrifos are the most common pesticides found in freshwater ecosystems throughout the world. Xing et al. [228] investigated the oxidative stress responses in the liver of common carp after exposure to atrazine and chlorpyrifos and found that exposure or their mixture could induce decrease in antioxidant enzyme activities and increase in MDA content in a dose-dependent manner. Eroğlu et al. [229] reported organophosphate pesticides produce oxidative stress due to the generation of free radicals, which alter the antioxidant defence system in erythrocytes and that vitamins $\mathrm{C}$ and $\mathrm{E}$ can act as protective role.

2.6. The Role of Oxidative Stress in Noise-Induced Hearing Damage. Noise is a disturbing and unwanted sound. Exposure to noise causes many health problems such as hearing loss, sleep disturbance, and impairs performance as well as effecting cognitive performance. It also increases aggression and reduces the processing of social cues seen as irrelevant to task performance, as well as leading to coronary heart disease, hypertension, higher blood pressure, increased mortality risk, serious psychological effects, headache, anxiety, and nausea ([230] and references within). Prolonged exposure to noise can also cause oxidative stress in the cochlea which results in the loss (via apoptotic pathways) of the outer hair cells of the organ of Corti. Increased noise exposure results in increased levels of reactive oxygen species formation that play a significant role in noise-induced hair cell death [231]. Acute as well as long-term exposure to noise can produce excessive free radicals alter endogenous antioxidative enzymes as superoxide dismutase, catalase, and glutathione peroxidase $[232,233]$.

In a study by Demirel et al. [230] the effect of noise on oxidative stress parameters in rats was analyzed by measuring malondialdehyde, nitric oxide levels, and glutathione peroxidase activity. The results showed an elevation in MDA level, an indicator of lipid peroxidation, as well as NO level and GSH-Px activity through noise exposure, suggesting that the presence of oxidative stress may have led to various degrees of damages in the cells. Additionally, increases in oxidative stress parameters, such as MDA level, and decreases in CAT and SOD activities in textile workers exposed to elevated levels of noise supports the hypothesis that noise causes oxidative stress [234]. It seems that noise might cause damage not only in the ears but also across the entire body, leading to oxidative stress [230]. In a study by van Campen et al. [235], the time course of ROS damage following exposure was assessed. Based upon oxidative DNA damage present in the cochlea following intense noise, the researchers postulate that the first $8 \mathrm{~h}$ following exposure might be a critical period for antioxidant treatment. Thus, the ROS quenching properties of antioxidants and medicinal plants are attracting more and more research to counteract noiseinduced oxidative stress. Manikandan and Devi [232] investigated the antioxidant property of alpha-asarone against noise stress induced changes in different regions of the rat brain and their data proved that the antioxidant property of alpha-asarone acts against noise stress induced damage. The aim of a study performed by Manikandan et al. [233] was to evaluate the protective effect of both ethyl acetate and methanolic extract of Acorus calamus against noise stress induced changes in the rat brain. Both the ethyl acetate and methanolic extract of Acorus calamus protected most of the changes in the rat brain induced by noise stress. $\mathrm{N}$ acetyl-cysteine also offered protection against noise-induced hearing loss in the Sprague Dawley rat [236]. The study by Ewert et al. [237] determined if administration of a combination of antioxidants 2,4-disulfonyl $\alpha$-phenyl tertiary butyl nitrone (HPN-07) and N-acetylcysteine could reduce both temporary and permanent hearing loss. The results showed that a combination of antioxidants HPN-07 and NAC can both enhance the temporary threshold shift recovery and prevent permanent threshold shift by reducing damage to the mechanical and neural components of the auditory system when administered shortly after blast exposure. Additionally, arboxy alkyl esters (esters of quinic acid found in fruits and vegetables) have been shown to improve DNA repair capacity of spiral ganglion neurons in response to noise stress [238].

The problem of oxidative stress in the production of hearing loss is even worse when the synergistic effects takes place since a broad range of environmental and occupational contaminants can interact with noise to enhance noiseinduced hearing loss, for example, through carbon monoxide and by acrylonitrile [239].

\subsection{Adverse or Insignificant Effects of Antioxidant Treatment} after Exposure to Environmental Pollutants. Administration of antioxidants in cases of environmentally induced oxidative stress does not always demonstrate protection (Table 5). Hackney et al. [240] analysed whether vitamin E supplementation protected against $\mathrm{O}_{3}$ exposure and found no significant differences between the vitamin $\mathrm{E}$ - and placebo-treated 
TABLE 5: Studies demonstrating adverse or insignificant effects of antioxidant treatment after exposure to environmental pollutants.

\begin{tabular}{|c|c|c|}
\hline Environmental pollutant & $\begin{array}{l}\text { Antioxidants displaying adverse or } \\
\text { insignificant effects }\end{array}$ & Study \\
\hline Ozone $\left(\mathrm{O}_{3}\right)$ & Vitamin $\mathrm{E}$ & Hackney et al. (1981) [240] \\
\hline Cigarette smoke & Beta-carotene (synthetic) & $\begin{array}{l}\text { Ruano-Ravina et al. (2006) [241] } \\
\text { Albanes (1999) [242] } \\
\text { Neuhouser et al. (2003) [243] }\end{array}$ \\
\hline Asbestos & Beta-carotene & van Helden et al. (2009) [244] \\
\hline & Beta-carotene & Stahl et al. (2006) [124] \\
\hline UVR & $\begin{array}{l}\text { Vitamin E and beta-carotene (no } \\
\text { protective effect) }\end{array}$ & $\begin{array}{l}\text { McArdle et al. (2004) [245] } \\
\text { Wolf et al. (1988) [246] } \\
\text { Garmyn et al. (1995) [247] }\end{array}$ \\
\hline $\begin{array}{l}\text { Bipyridinium herbicides (paraquat, } \\
\text { diquat and difenzoquat) }\end{array}$ & Iron and copper & $\begin{array}{l}\text { Korbashi et al. (1986) [248] } \\
\text { Kohen and Chevion (1985) [249] }\end{array}$ \\
\hline $\begin{array}{l}\text { Polychlorinated dibenzo-para-dioxins } \\
\text { (dioxins) and polychlorinated } \\
\text { dibenzofurans (furans) }\end{array}$ & Vitamin E (no protective effect) & $\begin{array}{l}\text { Latchoumycandane and Mathur (2002) } \\
{[250]}\end{array}$ \\
\hline \multirow{2}{*}{$\begin{array}{l}\text { No extraexposure to environmental } \\
\text { pollutants }\end{array}$} & $\begin{array}{l}\text { Green tea catechins (enhanced colon } \\
\text { carcinogenesis in rats) }\end{array}$ & Furukawa et al. (2003) [251] \\
\hline & $\begin{array}{l}\text { Melatonin (may exhibit carcinogenic } \\
\text { potential) }\end{array}$ & Sakano et al. (2004) [252] \\
\hline
\end{tabular}

groups. Another study demonstrated that in a high-risk group, such as smokers, high doses of beta-carotene increased the rate of lung cancer [241]. Additionally, the results of large, controlled trials of an intervention of beta-carotene supplementation did not support the detected beneficial associations or a role for supplemental beta-carotene in lung cancer prevention; instead, they provided striking evidence for its adverse effects among smokers [242]. McArdle et al. [118] investigated the effects of oral vitamin $\mathrm{E}$ and betacarotene supplementation on ultraviolet radiation-induced oxidative stress to the human skin. The results revealed that vitamin $\mathrm{E}$ or beta-carotene supplementation displayed no effect on the sensitivity of the skin to UVR. A study by Stahl et al. [122] was performed in which the antioxidant effect of carotenoids and tocopherols was investigated based on their ability to scavenge ROS generated during photooxidative stress. The antioxidants used in this study provided protection against erythema in humans and may be useful for diminishing the sensitivity to ultraviolet light (Table 5).

Iron and copper have been reported to aggravate the toxicity of paraquat in E. coli. Treatment with ferrous iron in a study by Korbashi et al. [248] led to an enhancement of bacterial killing by paraquat, whereas treatment with chelating agents, such as nitrilotriacetate and desferrioxamine, markedly reduced, up to complete abolishment, the toxic effects. Some compounds contribute to the antioxidant defence by chelating transition metals and preventing them from catalysing the production of free radicals in the cell. Metal-chelating antioxidants, such as transferrin, albumin, and ceruloplasmin, ameliorate radical production by inhibiting the Fenton reaction, which is catalysed by copper or iron. Latchoumycandane and Mathur [250] investigated whether treatment with vitamin $\mathrm{E}$ protects the rat testis against oxidative stress induced by tetrachlorodibenzodioxin and revealed that the activities of antioxidant enzymes and the levels of hydrogen peroxide and lipid peroxidation did not change in the animals coadministered tetrachlorodibenzodioxin and vitamin E. Although several studies have demonstrated the protective effect of antioxidant administration against oxidative stress, it is important to note that not all antioxidants exert health benefits.

2.8. What Could Be the Reason? The inappropriate use of dietary supplements may lead to "antioxidative stress." Detailed description of the negative effects of antioxidants can be found in publications by Poljsak et al., [253], Poljsak and Milisav [254], and references therein. Briefly, the intake of only one antioxidant may alter the complex system of endogenous antioxidative defence of cells or alter the cell apoptosis pathways [255]. The beneficial physiological cellular use of ROS is being demonstrated in different fields, including intracellular signalling and redox regulation and synthetic antioxidants cannot distinguish among the radicals that have a beneficial role and those that cause oxidative damage to biomolecules. If administration of antioxidant supplements decreases total ROS/RNS formation, it may also interfere with the immune system to fight bacteria and essential defensive mechanisms for removal of damaged cells, including those that are precancerous and cancerous [256]. When large amounts of antioxidant nutrients are taken, they can also act as prooxidants by increasing oxidative stress $[257,258]$. None of the major clinical studies using mortality or morbidity as an end point has found positive effects of antioxidant, such as vitamin $\mathrm{C}$, vitamin $\mathrm{E}$, or $\beta$-carotene, supplementation. Some recent studies demonstrated that antioxidant therapy displays no effect and can even increase mortality (The AlphaTocopherol, Beta-Carotene Cancer Prevention Study Group, 1994; [259-261], Heart Protection Study Collaborative Group, 
2002; Age-Related Eye Disease Study Research Group, 2001). On the other hand, antioxidant supplements do appear to be effective in lowering an individual's oxidative stress if his/her initial oxidative stress is above normal or above his/her set point of regulation [262, 263]. Thus, the antioxidant supplements may help the organism to correct the elevated levels of oxidative stress when it cannot be controlled by the endogenous antioxidants.

\section{Conclusions}

There is substantial evidence that environmental pollution increases oxidative stress [264] and that dietary antioxidant supplementation and/or increased ingestion of fruit and vegetable may play a role in neutralising or buffering the effects of pollutants that display oxidising properties. In vitro and in vivo studies suggest that antioxidant nutrients and related bioactive compounds common in fruits and vegetables can protect against environmental toxic insults. It is important to emphasise that antioxidants as dietary supplements can provide protection against ROS-induced damage under conditions of elevated oxidative stress to the organism. It could be postulated that antioxidants would be therapeutically effective under circumstances of elevated oxidative stress or in aged mammals exposed to a stressor that generates exacerbated oxidative injury. Evidence is presented demonstrating that synthetic antioxidant supplements cannot provide appropriate or complete protection against oxidative stress and damage under "normal" conditions and that the administration of antioxidants to prevent disease or the aging process is controversial under conditions of "normal" oxidative stress. Many clinical trials in which individuals received one or more synthetic antioxidants failed to detect beneficial effects (reviewed in [253]). Thus, the results of clinical trials of exogenous antioxidant intake are conflicting and contradictory. These findings indicate that other compounds in fruits and vegetables (possibly flavonoids) or a complex combination of compounds may contribute to the improvement in cardiovascular health and the decrease in cancer incidence detected among individuals who consume more of these foods $[265,266]$.

It must be understood that the use of synthetic vitamin supplements is not an alternative to regular consumption of fruits and vegetables. Cutler explains that most humans maintain stable levels of oxidative stress, and no matter how much additional antioxidant that individuals consume in their diet, no further decrease in oxidative stress occurs. However, antioxidant supplements do appear to be effective in lowering an individual's oxidative stress if his/her initial oxidative stress level is above normal or above his/her stably regulated level $[262,263]$. Thus, antioxidant supplements may only provide a benefit to an organism if it was necessary to correct a high level of oxidative stress that could not be controlled by endogenous antioxidants. All of this evidence indicates the need to determine an individual's oxidative stress level prior to the initiation of antioxidant supplement therapy. Both, the ROS/RNS formation and the antioxidative defense potential should be measured in a person in order to determine his/her oxidative stress status. Multiple methods of oxidative stress measurement are available today, each with their own advantages and disadvantages (reviewed in [253]).

In the end it should be stressed that more research should be performed to strengthen the evidence for dietary supplements as modulators of the adverse effects caused by increased exposure to environmental pollution.

\section{Conflict of Interests}

The authors declare that there is no conflict of interests regarding the publication of this paper.

\section{References}

[1] B. Halliwell and J. M. C. Gutteridge, Free Radicals in Biology and Medicine, Clarendon Press, Oxford, UK, 3rd edition, 1999.

[2] A. Valavanidis, T. Vlahogianni, M. Dassenakis, and M. Scoullos, "Molecular biomarkers of oxidative stress in aquatic organisms in relation to toxic environmental pollutants," Ecotoxicology and Environmental Safety, vol. 64, no. 2, pp. 178-189, 2006.

[3] C. E. Cross, G. Valacchi, B. Schock et al., "Environmental oxidant pollutant effects on biologic systems: a focus on micronutrient antioxidant-oxidant interactions," American Journal of Respiratory and Critical Care Medicine, vol. 166, supplement 1, pp. S44-S50, 2002.

[4] B. Brunekreef and S. T. Holgate, "Air pollution and health" The Lancet, vol. 360, no. 9341, pp. 1233-1242, 2002.

[5] F. J. Kelly and I. S. Mudway, "Protein oxidation at the air-lung interface," Amino Acids, vol. 25, no. 3-4, pp. 375-396, 2003.

[6] A. Nel, "Air pollution-related illness: effects of particles," Science, vol. 308, no. 5723, pp. 804-806, 2005.

[7] R. B. Schlesinger, N. Kunzli, G. M. Hidy, T. Gotschi, and M. Jerrett, "The health relevance of ambient particulate matter characteristics: Coherence of toxicological and epidemiological inferences," Inhalation Toxicology, vol. 18, no. 2, pp. 95-125, 2006.

[8] R. A. Floyd, "Measurement of oxidative stress in vivo," in The Oxygen Paradox, pp. 89-103, Cleup University Press, Padova, Italy, 1995.

[9] J. Nordberg and E. S. J. Arnér, "Reactive oxygen species, antioxidants, and the mammalian thioredoxin system," Free Radical Biology and Medicine, vol. 31, no. 11, pp. 1287-1312, 2001.

[10] H. J. Forman and A. Boveris, "Superoxide radical and hydrogen peroxide in mitochondria," in Free Radicals in Biology, E. Pryor, Ed., pp. 65-90, Academic Press, New York, NY, USA, 1982.

[11] K. Keyer and J. A. Imlay, "Superoxide accelerates DNA damage by elevating free-iron levels," Proceedings of the National Academy of Sciences of the United States of America, vol. 93, no. 24, pp. 13635-13640, 1996.

[12] F. Hutchinson, "Chemical changes induced in DNA by ionizing radiation," Progress in Nucleic Acid Research and Molecular Biology, vol. 32, pp. 115-154, 1985.

[13] B. N. Ames, "Dietary carcinogens and anticarcinogens," Science, vol. 221, no. 4617, pp. 1256-1263, 1983.

[14] E. C. Friedberg, L. D. McDaniel, and R. A. Schultz, DNA Repair and Mutagenesis, ASM Press, Washington, DC, USA, 1995.

[15] J. R. Speakman, A. van Acker, and E. J. Herper, "Age-related changes in the metabolism and body composition of three dog breeds and their relationship to life expectancy," Aging Cell, vol. 2, no. 5, pp. 265-275, 2003. 
[16] R. E. Shackelford, W. K. Kaufmann, and R. S. Paules, "Cell cycle control, checkpoint mechanisms, and genotoxic stress," Environmental Health Perspectives, vol. 107, no. 1, pp. 5-24, 1999.

[17] I. S. Mudway, D. Housley, R. Eccles et al., "Differential depletion of human respiratory tract antioxidants in response to ozone challenge," Free Radical Research, vol. 25, no. 6, pp. 499-513, 1996.

[18] W. A. Pryor, "How far does ozone penetrate into the pulmonary air/tissue boundary before it reacts?" Free Radical Biology and Medicine, vol. 12, no. 1, pp. 83-88, 1992.

[19] L. Grievink, A. G. Zijlstra, and X. Ke, "Double-blind intervention trial on modulation of ozone effects on pulmonary function by antioxidant supplements," American Journal of Epidemiology, vol. 149, no. 4, pp. 306-314, 1999.

[20] L. Grievink, A. G. Zijlstra, X. Ke, and B. Brunekreef, "Acute effects of ozone on pulmonary function in antioxidant supplemented cyclists," European Respiratory Journal, vol. 10, supplement 25, article 229S, 1997.

[21] J. M. Samet, G. E. Hatch, D. Horstman et al., "Effect of antioxidant supplementation on ozone-induced lung injury in human subjects," American Journal of Respiratory and Critical Care Medicine, vol. 164, no. 5, pp. 819-825, 2001.

[22] D. B. Menzel, "The toxicity of air pollution in experimental animals and humans: the role of oxidative stress," Toxicology Letters, vol. 72, no. 1-3, pp. 269-277, 1994.

[23] I. Romieu, J. J. Sienra-Monge, M. Ramírez-Aguilar et al., "Antioxidant supplementation and lung functions among children with asthma exposed to high levels of air pollutants," The American Journal of Respiratory and Critical Care Medicine, vol. 166, no. 5, pp. 703-709, 2002.

[24] I. Romieu, F. Meneses, M. Ramirez et al., "Antioxidant supplementation and respiratory functions among workers exposed to high levels of ozone," American Journal of Respiratory and Critical Care Medicine, vol. 158, no. 1, pp. 226-232, 1998.

[25] L. Grievink, H. A. Smit, and B. Brunekreef, "Anti-oxidants and air pollution in relation to indicators of asthma and COPD: a review of the current evidence," Clinical \& Experimental Allergy, vol. 30, no. 10, pp. 1344-1354, 2000.

[26] C. A. Ballinger, R. Cueto, G. Squadrito et al., "Antioxidantmediated augmentation of ozone-induced membrane oxidation," Free Radical Biology and Medicine, vol. 38, no. 4, pp. 515526, 2005.

[27] Z. Meng, G. Qin, B. Zhang et al., "Oxidative damage of sulfur dioxide inhalation on lungs and hearts of mice," Environmental Research, vol. 93, no. 3, pp. 285-292, 2003.

[28] Z. Meng and W. Bai, "Oxidation damage of sulfur dioxide on testicles of mice," Environmental Research, vol. 96, no. 3, pp. 298-304, 2004.

[29] Z. Ergonul, A. Erdem, Z. D. Balkanci, and K. Kilinc, "Vitamin E protects against lipid peroxidation due to cold- $\mathrm{SO}_{2}$ coexposure in mouse lung," Inhalation Toxicology, vol. 19, no. 2, pp. 161-168, 2007.

[30] Ö. Etlik, A. Tomur, M. Tuncer, A. Yalçin Ridvanağaoğlu, and O. Andaç, "Protective effect on antioxidant vitamins on red blood cell lipoperoxidation induced by $\mathrm{SO} 2$ inhalation," Journal of Basic and Clinical Physiology and Pharmacology, vol. 8, no. 12, pp. 31-43, 1997.

[31] J. Q. Zhao, Y. F. Wen, M. Bhadauria et al., "Protective effects of propolis on inorganic mercury induced oxidative stress in mice," Indian Journal of Experimental Biology, vol. 47, no. 4, pp. 264-269, 2009.
[32] O. Etlik, A. Tomur, M. N. Kutman, S. Yorukan, and O. Duman, "The effects of sulfur dioxide inhalation and antioxidant vitamins on red blood cell lipoperoxidation," Environmental Research, vol. 71, no. 1, pp. 25-28, 1995.

[33] H. Zhao, X. Xu, J. Na et al., "Protective effects of salicylic acid and vitamin $\mathrm{C}$ on sulfur dioxide-induced lipid peroxidation in mice," Inhalation Toxicology, vol. 20, no. 9, pp. 865-871, 2008.

[34] D. Wu and Z. Meng, "Effect of sulfur dioxide inhalation on the glutathione redox system in mice and protective role of sea buckthorn seed oil," Archives of Environmental Contamination and Toxicology, vol. 45, no. 3, pp. 423-428, 2003.

[35] S. C. Langley-Evans, G. J. Phillips, and A. A. Jackson, "Sulphur dioxide: a potent glutathione depleting agent," Comparative Biochemistry and Physiology C: Pharmacology Toxicology and Endocrinology, vol. 114, no. 2, pp. 89-98, 1996.

[36] A. S. Midgette, J. A. Baron, and T. E. Rohan, "Do cigarette smokers have diets that increase their risks of coronary heart disease and cancer?" American Journal of Epidemiology, vol. 137, no. 5, pp. 521-529, 1993.

[37] K. K. Banerjee, P. Marimuthu, A. Sarkar, and R. N. Chaudhuri, "Influence of cigarette smoking on Vitamin C, glutathione and lipid peroxidation status," Indian Journal of Public Health, vol. 42, no. 1, pp. 20-23, 1998.

[38] R. J. Bloomer, "Decreased blood antioxidant capacity and increased lipid peroxidation in young cigarette smokers compared to nonsmokers: impact of dietary intake," Nutrition Journal, vol. 6, article 39, 2007.

[39] A. Aycicek, O. Erel, and A. Kocyigit, "Decreased total antioxidant capacity and increased oxidative stress in passive smoker infants and their mothers," Pediatrics International, vol. 47, no. 6, pp. 635-639, 2005.

[40] M. Tsuchiya, A. Asada, E. Kasahara, E. F. Sato, M. Shindo, and $\mathrm{M}$. Inoue, "Smoking a single cigarette rapidly reduces combined concentrations of nitrate and nitrite and concentrations of antioxidants in plasma," Circulation, vol. 105, no. 10, pp. 11551157, 2002.

[41] J. F. Zhou, X. F. Yan, F. Z. Guo, N. Y. Sun, Z. J. Qian, and D. Y. Ding, "Effects of cigarette smoking and smoking cessation on plasma constituents and enzyme activities related to oxidative stress," Biomedical and Environmental Sciences, vol. 13, no. 1, pp. 44-55, 2000.

[42] S. Banerjee, R. Chattopadhyay, A. Ghosh et al., "Cellular and molecular mechanisms of cigarette smoke-induced lung damage and prevention by vitamin C," Journal of Inflammation, vol. 5, article 21, 2008.

[43] S. T. Mayne and B. Cartmel, "Antioxidant vitamin supplementation and lipid peroxidation in smokers," American Journal of Clinical Nutrition, vol. 69, no. 6, Article ID 1292, 1999.

[44] F. L. Chung, M. A. Morse, K. I. Eklind, Y. Xu, R. Rylander, and N. Krinsky, "Inhibition of the tobacco-specific nitrosamineinduced lung tumorigenesis by compounds derived from cruciferous vegetables and green tea," Annals of the New York Academy of Sciences, vol. 686, pp. 186-201, 1993.

[45] Y. Xu, C. T. Ho, S. G. Amin, C. Han, and F. L. Chung, "Inhibition of tobacco-specific nitrosamine-induced lung tumorigenesis in A/J mice by green tea and its major polyphenol as antioxidants," Cancer Research, vol. 52, no. 14, pp. 3875-3879, 1992.

[46] J. C. Jha, B. R. Maharjan, D. Adhikari et al., "Cigarette smoke induced oxidative insult in local population of Pokhara," Kathmandu University Medical Journal, vol. 5, no. 4, pp. 511-517, 2007.

[47] F. L. Chung, "The prevention of lung cancer induced by a tobacco-specific carcinogen in rodents by green and black 
tea," Proceedings of the Society for Experimental Biology and Medicine, vol. 220, no. 4, pp. 244-248, 1999.

[48] J. Zhou, F. Guo, and Z. Qian, "Effects of cigarette smoking on antioxidant vitamin and activities of antioxidases," Zhonghua $Y u$ Fang Yi Xue Za Zhi, vol. 31, no. 2, pp. 67-70, 1997.

[49] M. Dietrich, G. Block, E. P. Norkus et al., "Smoking and exposure to environmental tobacco smoke decrease some plasma antioxidants and increase $\gamma$-tocopherol in vivo after adjustment for dietary antioxidant intakes," American Journal of Clinical Nutrition, vol. 77, no. 1, pp. 160-166, 2003.

[50] J. Chávez, C. Cano, A. Souki et al., "Effect of cigarette smoking on the oxidant/antioxidant balance in healthy subjects," The American Journal of Therapeutics, vol. 14, no. 2, pp. 189-193, 2007.

[51] M. C. Polidori, P. Mecocci, W. Stahl, and H. Sies, "Cigarette smoking cessation increases plasma levels of several antioxidant micronutrients and improves resistance towards oxidative challenge," British Journal of Nutrition, vol. 90, no. 1, pp. 147-150, 2003.

[52] W. A. Pryor and D. F. Church, "Aldehydes, hydrogen peroxide, and organic radicals as mediators of ozone toxicity," Free Radical Biology and Medicine, vol. 11, no. 1, pp. 41-46, 1991.

[53] J. A. Last, W. M. Sun, and H. Witschi, "Ozone, NO, and $\mathrm{NO}_{2}$ : oxidant air pollutants and more," Environmental Health Perspectives, vol. 102, supplement 10, pp. 179-184, 1994.

[54] K. Kienast, M. Knorst, S. Lubjuhn, J. Muller-Quernheim, and R. Ferlinz, "Nitrogen dioxide-induced reactive oxygen intermediates production by human alveolar macrophages and peripheral blood mononuclear cells," Archives of Environmental Health, vol. 49, no. 4, pp. 246-250, 1994.

[55] D. J. Guth and R. D. Mavis, “The effect of lung $\alpha$-tocopherol content on the acute toxicity of nitrogen dioxide," Toxicology and Applied Pharmacology, vol. 84, no. 2, pp. 304-314, 1986.

[56] A. Sevanian, N. Elsayed, and A. D. Hacker, "Effects of vitamin E deficiency and nitrogen dioxide exposure on lung lipid peroxidation: use of lipid epoxides and malonaldehyde as measures of peroxidation," Journal of Toxicology and Environmental Health, vol. 10, no. 4-5, pp. 743-756, 1982.

[57] F. J. Kelly and T. D. Tetley, "Nitrogen dioxide depletes uric acid and ascorbic acid but not glutathione from lung lining fluid," Biochemical Journal, vol. 325, part 1, pp. 95-99, 1997.

[58] F. J. Kelly, A. Blomberg, A. Frew, S. T. Holgate, and T. Sandstrom, "Antioxidant kinetics in lung lavage fluid following exposure of humans to nitrogen dioxide," American Journal of Respiratory and Critical Care Medicine, vol. 154, no. 6, part 1, pp. 1700-1705, 1996.

[59] I. M. C. M. Rietjens, M. C. M. Poelen, R. A. Hempenius, M. J. Gijbels, and G. M. Alink, "Toxicity of ozone and nitrogen dioxide to alveolar macrophages: comparative study revealing differences in their mechanism of toxic action," Journal of Toxicology and Environmental Health, vol. 19, no. 4, pp. 555-568, 1986.

[60] V. Mohsenin, "Effect of vitamin $\mathrm{C}$ on $\mathrm{NO}_{2}$-induced airway hyperresponsiveness in normal subjects: a randomized doubleblind experiment," American Review of Respiratory Disease, vol. 136, no. 6, pp. 1408-1411, 1987.

[61] S. M. Khopde, K. I. Priyadarsini, T. Mukherjee, P. B. Kulkarni, J. G. Satav, and R. K. Bhattacharya, "Does $\beta$-carotene protect membrane lipids from nitrogen dioxide?” Free Radical Biology and Medicine, vol. 25, no. 1, pp. 66-71, 1998.

[62] F. Böhm, R. Edge, M. Burke, and T. G. Truscott, "Dietary uptake of lycopene protects human cells from singlet oxygen and nitrogen dioxide-ROS components from cigarette smoke," Journal of Photochemistry and Photobiology B: Biology, vol. 64, no. 2-3, pp. 176-178, 2001.

[63] B. González-Flecha, "Oxidant mechanisms in response to ambient air particles," Molecular Aspects of Medicine, vol. 25, no. (1-2), pp. 169-182, 2004.

[64] R. A. Pinho, P. C. L. Silveira, L. A. Silva, E. Luiz Streck, F. DalPizzol, and J. C. F. Moreira, "N-Acetylcysteine and deferoxamine reduce pulmonary oxidative stress and inflammation in rats after coal dust exposure," Environmental Research, vol. 99, no. 3, pp. 355-360, 2005.

[65] K. Aganasur, P. Jeff Inmon, L. A. Dailey, M. C. Madden, A. J. Ghio, and J. E. Gallagher, "Air pollution particles mediated oxidative DNA base damage in a cell free system and in human airway epithelial cells in relation to particulate metal content and bioreactivity," Chemical Research in Toxicology, vol. 14, pp. 879-887, 2001.

[66] C. Hatzis, J. J. Godleski, B. González-Flecha, J. M. Wolfson, and P. Koutrakis, "Ambient particulate matter exhibits direct inhibitory effects on oxidative stress enzymes," Environmental Science and Technology, vol. 40, no. 8, pp. 2805-2811, 2006.

[67] F. P. Possamai, S. Á. Júnior, E. B. Parisotto et al., "Antioxidant intervention compensates oxidative stress in blood of subjects exposed to emissions from a coal electric-power plant in South Brazil," Environmental Toxicology and Pharmacology, vol. 30, no. 2, pp. 175-180, 2010.

[68] D. W. Kamp, P. Graceffa, W. A. Pryor, and S. A. Weitzman, "The role of free radicals in asbestos-induced diseases," Free Radical Biology and Medicine, vol. 12, no. 4, pp. 293-315, 1992.

[69] C. Walker, J. Everitt, and J. C. Barrett, "Possible cellular and molecular mechanisms for asbestos carcinogenicity," The American Journal of Industrial Medicine, vol. 21, no. 2, pp. 253-273, 1992.

[70] S. Q. Luo, X. Z. Liu, and C. J. Wang, "Inhibitory effect of green tea extract on the carcinogenesis induced by asbestos plus benzo(a)pyrene in rat," Biomedical and Environmental Sciences, vol. 8, no. 1, pp. 54-58, 1995.

[71] E. Lewczuk and H. Owczarek, "The role of oxygen free radicals in asbestos cytotoxicity," Medycyna pracy, vol. 43, no. 4, pp. 335342, 1992.

[72] C. L. Fattman, R. J. Tan, J. M. Tobolewski, and T. D. Oury, "Increased sensitivity to asbestos-induced lung injury in mice lacking extracellular superoxide dismutase," Free Radical Biology and Medicine, vol. 40, no. 4, pp. 601-607, 2006.

[73] T. K. Hei, A. Xu, S. X. Huang, and Y. Zhao, "Mechanism of fiber carcinogenesis: from reactive radical species to silencing of the $\beta$ igH3 gene," Inhalation Toxicology, vol. 18, no. 12, pp. 985-990, 2006.

[74] D. Pelclová, Z. Fenclová, P. Kacer, M. Kuzma, T. Navrátil, and J. Lebedová, "Increased 8-isoprostane, a marker of oxidative stress in exhaled breath condensate in subjects with asbestos exposure," Industrial Health, vol. 46, no. 5, pp. 484-489, 2008.

[75] B. Marczynski, P. Rozynek, T. Kraus, S. Schlösser, H. J. Raithel, and X. Baur, 'Levels of 8-hydroxy-2'-deoxyguanosine in DNA of white blood cells from workers highly exposed to asbestos in Germany," Mutation Research: Genetic Toxicology and Environmental Mutagenesis, vol. 468, no. 2, pp. 195-202, 2000.

[76] V. J. Thannickal and B. L. Fanburg, "Reactive oxygen species in cell signaling," American Journal of Physiology: Lung Cellular and Molecular Physiology, vol. 279, no. 6, pp. L1005-L1028, 2000. 
[77] B. N. Ames, "Delaying the mitochondrial decay of aging," Annals of the New York Academy of Sciences, vol. 1019, pp. 406411, 2004.

[78] R. Radi, G. Peluffo, M. N. Alvarez, M. Naviliat, and A. Cayota, "Unraveling peroxynitrite formation in biological systems," Free Radical Biology and Medicine, vol. 30, no. 5, pp. 463-488, 2001.

[79] W. C. Willett, "The Mediterranean diet: science and practice," Public Health Nutrition, vol. 9, no. 1, pp. 105-110, 2006.

[80] A. Sevanian, A. D. Hacker, and N. Elsayed, "Influence of vitamin $\mathrm{E}$ and nitrogen dioxide on lipid peroxidation in rat lung and liver microsomes," Lipids, vol. 17, no. 4, pp. 269-277, 1982.

[81] G. E. Hatch, "Asthma, inhaled oxidants, and dietary antioxidants," American Journal of Clinical Nutrition, vol. 61, supplement 3, pp. 625S-630S, 1995.

[82] L. Risom, P. Møller, and S. Loft, "Oxidative stress-induced DNA damage by particulate air pollution," Mutation Research: Fundamental and Molecular Mechanisms of Mutagenesis, vol. 592, no. 1-2, pp. 119-137, 2005.

[83] L. L. Greenwell, T. Moreno, and R. J. Richards, "Pulmonary antioxidants exert differential protective effects against urban and industrial particulate matter," Journal of Biosciences, vol. 28, no. 1, pp. 101-107, 2003.

[84] A. Sperati, D. D. Abeni, C. Tagesson, F. Forastiere, M. Miceli, and O. Axelson, "Exposure to indoor background radiation and urinary concentrations of 8-hydroxydeoxyguanosine, a marker of oxidative DNA damage," Environmental Health Perspectives, vol. 107, no. 3, pp. 213-215, 1999.

[85] J. K. Tak and J. W. Park, "The use of ebselen for radioprotection in cultured cells and mice," Free Radical Biology and Medicine, vol. 46, no. 8, pp. 1177-1185, 2009.

[86] S. Kilciksiz, C. Demirel, S. E. Ayhan et al., "N-acetylcysteine ameliorates nitrosative stress on radiation-inducible damage in rat liver," Journal of B.U.ON., vol. 16, no. 1, pp. 154-159, 2011.

[87] S. Kilciksiz, C. Demirel, N. Erdal et al., "The effect of Nacetylcysteine on biomarkers for radiation-induced oxidative damage in a rat model," Acta Medica Okayama, vol. 62, no. 6, pp. 403-409, 2008.

[88] V. Benković, A. H. Knezević, D. Dikić et al., "Radioprotective effects of quercetin and ethanolic extract of propolis in gammairradiated mice," Archives of Industrial Hygiene and Toxicology, vol. 60, no. 2, pp. 129-138, 2009.

[89] G. C. Jagetia, "Radioprotection and radiosensitization by curcumin," Advances in Experimental Medicine and Biology, vol. 595, pp. 301-320, 2007.

[90] P. Kovacic and R. Somanathan, "Electromagnetic fields: mechanism, cell signaling, other bioprocesses, toxicity, radicals, antioxidants and beneficial effects," Journal of Receptors and Signal Transduction, vol. 30, no. 4, pp. 214-226, 2010.

[91] M. Simkó and M. Mattsson, "Extremely low frequency electromagnetic fields as effectors of cellular responses in vitro: possible immune cell activation," Journal of Cellular Biochemistry, vol. 93, no. 1, pp. 83-92, 2004.

[92] A. V. Musaev, L. F. Ismailova, A. B. Shabanova, A. A. Magerramov, E. I. Iusifov, and A. M. Gadzhiev, "Pro- and antioxidant effect of electromagnetic fields of extremely high frequency $(460 \mathrm{MHz})$ on brain tissues in experiment," Voprosy Kurortologii, Fizioterapii, i Lechebnoi Fizicheskoi Kultury, no. 2, pp. 19-23, 2004.

[93] F. Ozguner, Y. Bardak, and S. Comlekci, "Protective effects of melatonin and caffeic acid phenethyl ester against retinal oxidative stress in long-term use of mobile phone: a comparative study," Molecular and Cellular Biochemistry, vol. 282, no. 1-2, pp. 83-88, 2006.

[94] J. Jajte, M. Zmyślony, J. Palus, E. Dziubaltowska, and E. Rajkowska, "Protective effect of melatonin against in vitro iron ions and $7 \mathrm{mT} 50 \mathrm{~Hz}$ magnetic field-induced DNA damage in rat lymphocytes," Mutation Research, vol. 483, no. (1-2), pp. 5764, 2001.

[95] A. Ilhan, A. Gurel, F. Armutcu et al., "Ginkgo biloba prevents mobile phone-induced oxidative stress in rat brain," Clinica Chimica Acta, vol. 340, no. 1-2, pp. 153-162, 2004.

[96] M. Guney, F. Ozguner, B. Oral, N. Karahan, and T. Mungan, "900 MHz radiofrequency-induced histopathologic changes and oxidative stress in rat endometrium: protection by vitamins E and C," Toxicology and Industrial Health, vol. 23, no. 7, pp. 411420, 2007.

[97] C. O. Wambi, J. K. Sanzari, C. M. Sayers et al., "Protective effects of dietary antioxidants on proton total-body irradiationmediated hematopoietic cell and animal survival," Radiation Research, vol. 172, no. 2, pp. 175-186, 2009.

[98] E. R. Andrade, I. B. M. Cruz, V. V. R. Andrade et al., "Evaluation of the potential protective effects of ad libitum black grape juice against liver oxidative damage in whole-body acute $\mathrm{X}$ irradiated rats," Food and Chemical Toxicology, vol. 49, no. 4, pp. 1026-1032, 2011.

[99] G. G. Nair and C. K. K. Nair, "Protection of cellular DNA and membrane from $\gamma$-radiation-induced damages and enhancement in DNA repair by sesamol," Cancer Biotherapy and Radiopharmaceuticals, vol. 25, no. 6, pp. 629-635, 2010.

[100] M. A. El-Missiry, T. A. Fayed, M. R. El-Sawy, and A. A. El-Sayed, "Ameliorative effect of melatonin against gamma-irradiationinduced oxidative stress and tissue injury," Ecotoxicology and Environmental Safety, vol. 66, no. 2, pp. 278-286, 2007.

[101] M. Karbownik and R. J. Reiter, "Antioxidative effects of melatonin in protection against cellular damage caused by ionizing radiation," Experimental Biology and Medicine, vol. 225, no. 1, pp. 9-22, 2000.

[102] C. K. K. Nair, P. U. Devi, R. Shimanskaya et al., "Water soluble vitamin E (TMG) as a radioprotector," Indian Journal of Experimental Biology, vol. 41, no. 12, pp. 1365-1371, 2003.

[103] E. Noaman, A. M. Zahran, A. M. Kamal, and M. F. Omran, "Vitamin E and selenium administration as a modulator of antioxidant defense system: biochemical assessment and modification," Biological Trace Element Research, vol. 86, no. 1, pp. 55-64, 2002.

[104] M. Berbée, Q. Fu, M. Boerma, J. Wang, K. S. Kumar, and M. Hauer-Jensen, " $\gamma$-Tocotrienol ameliorates intestinal radiation injury and reduces vascular oxidative stress after total-body irradiation by an HMG-CoA Reductase-dependent mechanism," Radiation Research, vol. 171, no. 5, pp. 596-605, 2009.

[105] M. Srinivasan, N. Devipriya, K. B. Kalpana, and V. P. Menon, "Lycopene: an antioxidant and radioprotector against $\gamma$ radiation-induced cellular damages in cultured human lymphocytes," Toxicology, vol. 262, no. 1, pp. 43-49, 2009.

[106] Y. Hu, D. Guo, P. Liu et al., "Bioactive components from the tea polyphenols influence on endogenous antioxidant defense system and modulate inflammatory cytokines after total-body irradiation in mice," Phytomedicine, vol. 18, no. 11, pp. 970-975, 2011.

[107] F. I. Wolf, S. Fasanella, B. Tedesco et al., "Peripheral lymphocyte 8-OHdG levels correlate with age-associated increase of tissue oxidative DNA damage in Sprague-Dawley rats. Protective 
effects of caloric restriction," Experimental Gerontology, vol. 40, no. 3, pp. 181-188, 2005.

[108] G. Güler, Z. Turkozer, A. Tomruk, and N. Seyhan, "The protective effects of $\mathrm{N}$-acetyl-L-cysteine and Epigallocatechin-3- gallate on electric field-induced hepatic oxidative stress," International Journal of Radiation Biology, vol. 84, no. 8, pp. 669-680, 2008.

[109] E. Ozgur, G. Güler, and N. Seyhan, "Mobile phone radiationinduced free radical damage in the liver is inhibited by the antioxidants $\mathrm{N}$-acetyl cysteine and epigallocatechin-gallate," International Journal of Radiation Biology, vol. 86, no. 11, pp. 935-945, 2010.

[110] M. Simkó, "Cell type specific redox status is responsible for diverse electromagnetic field effects," Current Medicinal Chemistry, vol. 14, no. 10, pp. 1141-1152, 2007.

[111] R. J. Reiter, "Melatonin suppression by static and extremely low frequency electromagnetic fields: relationship to the reported increased incidence of cancer," Reviews on Environmental Health, vol. 10, no. 3-4, pp. 171-186, 1994.

[112] M. Naziroğlu and N. Gümral, "Modulator effects of L-carnitine and selenium on wireless devices $(2.45 \mathrm{GHz})$-induced oxidative stress and electroencephalography records in brain of rat," International Journal of Radiation Biology, vol. 85, no. 8, pp. 680-689, 2009.

[113] J. G. Peak, M. J. Peak, R. A. Sikorski, and R. A. Jones, "Induction of DNA-protein cross-links in human cells by ultraviolet and visible radiations: action spectrum," Photochemistry and Photobiology, vol. 41, no. 3, pp. 295-302, 1988.

[114] B. C. Beehler, J. Przybyszewski, H. B. Box, and M. F. KuleszMartin, "Formation of 8-hydroxydeoxyguanosine within DNA of mouse keratinocytes exposed in culture to UVB and $\mathrm{H}_{2} \mathrm{O}_{2}$," Carcinogenesis, vol. 13, no. 11, pp. 2003-2007, 1992.

[115] T. R. Berton, D. L. Mitchell, S. M. Fischer, and M. F. Locniskar, "Epidermal proliferation but not the quantity of DNA photodamage is correlated with UV-induced mouse skin carcinogenesis," Journal of Investigative Dermatology, vol. 109, no. 3, pp. 340-347, 1997.

[116] G. Li, D. L. Mitchell, V. C. Ho, J. C. Reed, and V. A. Tron, "Decreased DNA repair but normal apoptosis in ultravioletirradiated skin of p53-transgenic mice," American Journal of Pathology, vol. 148, no. 4, pp. 1113-1123, 1996.

[117] H. Masaki, "Role of antioxidants in the skin: anti-aging effects," Journal of Dermatological Science, vol. 58, no. 2, pp. 85-90, 2010.

[118] F. McArdle, L. E. Rhodes, R. Parslew, C. I. A. Jack, P. S. Friedmann, and M. J. Jackson, "UVR-induced oxidative stress in human skin in vivo: effects of oral vitamin C supplementation," Free Radical Biology and Medicine, vol. 33, no. 10, pp. 1355-1362, 2002.

[119] P. G. Humbert, M. Haftek, P. Creidi et al., “Topical ascorbic acid on photoaged skin. Clinical, topographical and ultrastructural evaluation: double-blind study vs. placebo," Experimental Dermatology, vol. 12, no. 3, pp. 237-244, 2003.

[120] E. F. Ritter, M. Axelrod, K. W. Minn et al., "Modulation of ultraviolet light-induced epidermal damage: beneficial effects of tocopherol," Plastic and Reconstructive Surgery, vol. 100, no. 4, pp. 973-980, 1997.

[121] L. Packer, S. U. Weber, and G. Rimbach, "Molecular aspects of $\alpha$-tocotrienol antioxidant action and cell signalling," Journal of Nutrition, vol. 131, no. 2, pp. 369S-373S, 2001.

[122] W. Stahl, U. Heinrich, H. Jungmann, H. Sies, and H. Tronnier, "Carotenoids and carotenoids plus vitamin E protect against ultraviolet light-induced erythema in humans," American Journal of Clinical Nutrition, vol. 71, no. 3, pp. 795-798, 2000.

[123] L. H. Kligman and A. M. Kligman, "The nature of photoaging: its prevention and repair," Photodermatology, vol. 3, no. 4, pp. 215-227, 1986.

[124] W. Stahl, H. Mukhtar, F. Afaq, and H. Sies, "Vitamins and polyphenols XE polyphenols in systemic photoprotection," in Skin Aging, B. Gilchrest and J. Krutmann, Eds., Springer, Berlin, Germany, 2006.

[125] H. Sies and W. Stahl, "Carotenoids and UV protection," Photochemical and Photobiological Sciences, vol. 3, no. 8, pp. 749-752, 2004.

[126] S. Cho, D. H. Lee, C. H. Won et al., "Differential effects of lowdose and high-dose beta-carotene supplementation on the signs of photoaging and type I procollagen gene expression in human skin in vivo," Dermatology, vol. 221, no. 2, pp. 160-171, 2010.

[127] Y. Shindo, E. Witt, and L. Packer, "Antioxidant defense mechanisms in murine epidermis and dermis and their responses to ultraviolet light," Journal of Investigative Dermatology, vol. 100, no. 3, pp. 260-265, 1993.

[128] L. Packer and G. Valacchi, "Antioxidants and the response of skin to oxidative stress: vitamin E as a key indicator," Skin Pharmacology and Applied Skin Physiology, vol. 15, no. 5, pp. 282-290, 2002.

[129] J. J. Thiele, "Oxidative targets in the stratum corneum: a new basis for antioxidative strategies," Skin Pharmacology and Applied Skin Physiology, vol. 14, no. 1, pp. 87-91, 2001.

[130] J. D. Ribaya-Mercado, M. Garmyn, B. A. Gilchrest, and R. M. Russell, "Skin lycopene is destroyed preferentially over $\beta$ carotene during ultraviolet irradiation in humans," Journal of Nutrition, vol. 125, no. 7, pp. 1854-1859, 1995.

[131] U. Heinrich, C. Gärtner, M. Wiebusch et al., "Supplementation with $\beta$-carotene or a similar amount of mixed carotenoids protects humans from UV-induced erythema," Journal of Nutrition, vol. 133, no. 1, pp. 98-101, 2003.

[132] J. Lee, S. Jiang, N. Levine, and R. R. Watson, "Carotenoid supplementation reduces erythema in human skin after simulated solar radiation exposure," Proceedings of the Society for Experimental Biology and Medicine, vol. 223, no. 2, pp. 170-174, 2000.

[133] W. Stahl, A. Junghans, B. de Boer, E. S. Driomina, K. Briviba, and H. Sies, "Carotenoid mixtures protect multilamellar liposomes against oxidative damage: synergistic effects of lycopene and lutein," FEBS Letters, vol. 427, no. 2, pp. 305-308, 1998.

[134] O. Aust, W. Stahl, H. Sies, H. Tronnier, and U. Heinrich, "Supplementation with tomato-based products increases lycopene, phytofluene, and phytoene levels in human serum and protects against UV-light-induced erythema," International Journal for Vitamin and Nutrition Research, vol. 75, no. 1, pp. 54-60, 2005.

[135] S. L. Yeh, C. S. Huang, and M. L. Hu, "Lycopene enhances UVAinduced DNA damage and expression of heme oxygenase-1 in cultured mouse embryo fibroblasts," European Journal of Nutrition, vol. 44, no. 6, pp. 365-370, 2005.

[136] F. Afaq and H. Mukhtar, "Photochemoprevention by botanical antioxidants," Skin Pharmacology and Physiology, vol. 15, pp. 297-306, 2002.

[137] S. K. Katiyar, N. Ahmad, and H. Mukhtar, "Green tea and skin," Archives of Dermatology, vol. 136, no. 8, pp. 989-994, 2000.

[138] S. K. Katiyar, "Skin photoprotection by green tea: antioxidant and immunomodulatory effects," Current Drug Targets: Immune, Endocrine and Metabolic Disorders, vol. 3, no. 3, pp. 234-242, 2003. 
[139] S. K. Katiyar, M. Vaid, H. van Steeg, and S. M. Meeran, “Green tea polyphenols prevent uv-induced immunosuppression by rapid repair of DNA damage and enhancement of nucleotide excision repair genes," Cancer Prevention Research, vol. 3, no. 2, pp. 179-189, 2010.

[140] Y. P. Lu, Y. R. Lou, Q. Y. Peng, J. G. Xie, P. Nghiem, and A. H. Conney, "Effect of caffeine on the ATR/Chk1 pathway in the epidermis of UVB-irradiated mice," Cancer Research, vol. 68, no. 7, pp. 2523-2529, 2008.

[141] R. P. Singh and R. Agarwal, "Flavonoid antioxidant silymarin and skin cancer," Antioxidants and Redox Signaling, vol. 4, no. 4, pp. 655-663, 2002.

[142] F. Bonina, M. Lanza, L. Montenegro et al., "Flavonoids as potential protective agents against photo-oxidative skin damage," International Journal of Pharmaceutics, vol. 145, no. 1-2, pp. 8794, 1996.

[143] H. Wei, R. Bowen, Q. Cai, S. Barnes, and Y. Wang, "Antioxidant and antipromotional effects of the soybean isoflavone genistein," Proceedings of the Society for Experimental Biology and Medicine, vol. 208, no. 1, pp. 124-130, 1995.

[144] C. Saliou, G. Rimbach, H. Moini et al., "Solar ultravioletinduced erythema in human skin and nuclear factor-kappa-Bdependent gene expression in keratinocytes are modulated by a French maritime pine bark extract," Free Radical Biology and Medicine, vol. 30, no. 2, pp. 154-160, 2001.

[145] D. Bagchi, M. Bagchi, E. A. Hassoun, and S. J. Stohs, "In vitro and in vivo generation of reactive oxygen species, DNA damage and lactate dehydrogenase leakage by selected pesticides," Toxicology, vol. 104, no. 1-3, pp. 129-140, 1995.

[146] V. L. de Liz Oliveira Cavalli, D. Cattani, C. E. Heinz Rieg et al., "Roundup disrupts male reproductive functions by triggering calcium-mediated cell death in rat testis and Sertoli cells," Free Radical Biology and Medicine, vol. 65, pp. 335-346, 2013.

[147] S. Olgun and H. P. Misra, "Pesticides induced oxidative stress in thymocytes," Molecular and Cellular Biochemistry, vol. 290, no. 1-2, pp. 137-144, 2006.

[148] E. Hassoun, M. Bagchi, D. Bagchi, and S. J. Stohs, "Comparative studies on lipid peroxidation and DNA-single strand breaks induced by lindane, DDT, chlordane and endrin in rats," Comparative Biochemistry and Physiology C, vol. 104, no. 3, pp. 427-431, 1993.

[149] J. S. Bus, S. D. Aust, and J. E. Gibson, "Paraquat toxicity: proposed mechanism of action involving lipid peroxidation," Environmental Health Perspectives, vol. 16, pp. 139-146, 1976.

[150] I. N. Pérez-Maldonado, C. Herrera, L. E. Batres, R. GonzálezAmaro, F. Díaz-Barriga, and L. Yáñez, "DDT-induced oxidative damage in human blood mononuclear cells," Environmental Research, vol. 98, no. 2, pp. 177-184, 2005.

[151] A. P. Senft, T. P. Dalton, D. W. Nebert, M. B. Genter, R. J. Hutchinson, and H. G. Shertzer, "Dioxin increases reactive oxygen production in mouse liver mitochondria," Toxicology and Applied Pharmacology, vol. 178, no. 1, pp. 15-21, 2002.

[152] O. Ciftci, S. Tanyildizi, and A. Godekmerdan, "Protective effect of curcumin on immune system and body weight gain on rats intoxicated with 2,3,7,8-Tetrachlorodibenzo-p-dioxin (TCDD)," Immunopharmacology and Immunotoxicology, vol. 32, no. 1, pp. 99-104, 2010.

[153] Y. Hung, G. S. Huang, V. M. Sava, V. A. Blagodarsky, and M. Hong, "Protective effects of tea melanin against 2,3,7,8-tetrachlorodibenzo- $p$-dioxin-induced toxicity: antioxidant activity and aryl hydrocarbon receptor suppressive effect," Biological and Pharmaceutical Bulletin, vol. 29, no. 11, pp. 2284-2291, 2006.
[154] F. Gultekin, N. Delibas, S. Yasar, and I. Kilinc, "In vivo changes in antioxidant systems and protective role of melatonin and a combination of vitamin $\mathrm{C}$ and vitamin $\mathrm{E}$ on oxidative damage in erythrocytes induced by chlorpyrifos-ethyl in rats," Archives of Toxicology, vol. 75, no. 2, pp. 88-96, 2001.

[155] Y. Zhu, A. L. Kalen, L. Li et al., "Polychlorinated-biphenylinduced oxidative stress and cytotoxicity can be mitigated by antioxidants after exposure," Free Radical Biology and Medicine, vol. 47, no. 12, pp. 1762-1771, 2009.

[156] P. Ramadass, P. Meerarani, M. Toborek, L. W. Robertson, and B. Hennig, "Dietary flavonoids modulate PCB-induced oxidative stress, CYP1A1 induction, and AhR-DNA binding activity in vascular endothelial cells," Toxicological Sciences, vol. 76, no. 1, pp. 212-219, 2003.

[157] S. Park, J. Jang, C. Chen, H. Na, and Y. Surh, "A formulated red ginseng extract rescues $\mathrm{PC} 12$ cells from $\mathrm{PCB}$-induced oxidative cell death through Nrf2-mediated upregulation of heme oxygenase-1 and glutamate cysteine ligase," Toxicology, vol. 278, no. 1, pp. 131-139, 2010.

[158] N. Sridevi, P. Venkataraman, K. Senthilkumar, G. Krishnamoorthy, and J. Arunakaran, "Oxidative stress modulates membrane bound ATPases in brain regions of PCB (Aroclor 1254) exposed rats: protective role of $\alpha$-tocopherol," Biomedicine and Pharmacotherapy, vol. 61, no. 7, pp. 435-440, 2007.

[159] P. Murugesan, T. Muthusamy, K. Balasubramanian, and J. Arunakaran, "Studies on the protective role of vitamin C and E against polychlorinated biphenyl (Aroclor 1254)_induced oxidative damage in Leydig cells," Free Radical Research, vol. 39, no. 11, pp. 1259-1272, 2005.

[160] O. Ciftci, I. Ozdemir, S. Tanyildizi, S. Yildiz, and H. Oguzturk, "Antioxidative effects of curcumin, $\beta$-myrcene and 1,8-cineole against 2,3,7,8-tetrachlorodibenzo- $p$-dioxin-induced oxidative stress in rats liver," Toxicology and Industrial Health, vol. 27, no. 5, pp. 447-453, 2011.

[161] F. Karatas, S. Servi, H. Kara, T. R. Kiran, and S. Saydam, "Investigation of oxidative status of the 2-furan-2-yl- $1 \mathrm{H}$-benzimidazole in rats," Biological Trace Element Research, vol. 126, no. 1-3, pp. 214-221, 2008.

[162] T. Ishida, T. Takeda, T. Koga et al., "Attenuation of 2,3,7,8tetrachlorodibenzo-p-dioxin toxicity by resveratrol: a comparative study with different routes of administration," Biological and Pharmaceutical Bulletin, vol. 32, no. 5, pp. 876-881, 2009.

[163] H. Türkez, F. Geyikoğlu, M. I. Yousef, B. Toğar, and S. Vançelik, "Propolis alleviates 2,3,7,8-Tetrachlorodibenzo-pdioxin-induced histological changes, oxidative stress and DNA damage in rat liver," Toxicology and Industrial Health, vol. 29, no. 8, pp. 677-685, 2012.

[164] N. H. Song, X. L. Yin, G. F. Chen, and H. Yang, "Biological responses of wheat (Triticum aestivum) plants to the herbicide chlorotoluron in soils," Chemosphere, vol. 68, no. 9, pp. 17791787, 2007.

[165] D. Bagchi, G. Bhattacharya, and S. J. Stohs, "In vitro and in vivo induction of heat shock (stress) protein (Hsp) gene expression by selected pesticides," Toxicology, vol. 112, no. 1, pp. 57-68, 1996.

[166] G. E. Kisby, J. F. Muniz, J. Scherer et al., "Oxidative stress and DNA damage in agricultural workers," Journal of Agromedicine, vol. 14, no. 2, pp. 206-214, 2009.

[167] X. Yi, H. Ding, Y. Lu, H. Liu, M. Zhang, and W. Jiang, "Effects of long-term alachlor exposure on hepatic antioxidant defense and detoxifying enzyme activities in crucian carp (Carassius auratus)," Chemosphere, vol. 68, no. 8, pp. 1576-1581, 2007. 
[168] C. Kesavachandran, V. K. Singh, N. Mathur et al., "Possible mechanism of pesticide toxicity-related oxidative stress leading to airway narrowing," Redox Report, vol. 11, no. 4, pp. 159-162, 2006.

[169] G. F. Combs Jr. and F. J. Peterson, "Protection against acute paraquat toxicity by dietary selenium in the chick," Journal of Nutrition, vol. 113, no. 3, pp. 538-545, 1983.

[170] M. Glass, M. W. Sutherland, H. J. Forman, and A. B. Fisher, "Selenium deficiency potentiates paraquat-induced lipid peroxidation in isolated perfused rat lung," Journal of Applied Physiology, vol. 59, no. 2, pp. 619-622, 1985.

[171] W. H. Cheng, Y. S. Ho, B. A. Valentine, D. A. Ross, G. F. Combs Jr., and X. G. Lei, "Cellular glutathione peroxidase is the mediator of body selenium to protect against paraquat lethality in transgenic mice," Journal of Nutrition, vol. 128, no. 7, pp. 10701076, 1998.

[172] M. Takizawa, K. Komori, Y. Tampo, and M. Yonaha, "Paraquatinduced oxidative stress and dysfunction of cellular redox systems including antioxidative defense enzymes glutathione peroxidase and thioredoxin reductase," Toxicology in Vitro, vol. 21, no. 3, pp. 355-363, 2007.

[173] M. Aono, H. Saji, K. Fujiyama, M. Sugita, N. Kondo, and K. Tanaka, "Decrease in activity of glutathione reductase enhances paraquat sensitivity in transgenic Nicotiana tabacum," Plant Physiology, vol. 107, no. 2, pp. 645-648, 1995.

[174] O. Akturk, H. Demirin, R. Sutcu, N. Yilmaz, H. Koylu, and I. Altuntas, "The effects of diazinon on lipid peroxidation and antioxidant enzymes in rat heart and ameliorating role of vitamin E and vitamin C," Cell Biology and Toxicology, vol. 22, no. 6, pp. 455-461, 2006.

[175] R. S. Verma, A. Mehta, and N. Srivastava, "In vivo chlorpyrifos induced oxidative stress: attenuation by antioxidant vitamins," Pesticide Biochemistry and Physiology, vol. 88, no. 2, pp. 191-196, 2007.

[176] I. Altuntas, N. Delibas, and R. Sutcu, "The effects of organophosphate insecticide methidathion on lipid peroxidation and anti-oxidant enzymes in rat erythrocytes: role of vitamins $\mathrm{E}$ and C, Human and Experimental Toxicology, vol. 21, no. 12, pp. 681685, 2002.

[177] A. Goel, V. Dani, and D. K. Dhawan, "Protective effects of zinc on lipid peroxidation, antioxidant enzymes and hepatic histoarchitecture in chlorpyrifos-induced toxicity," ChemicoBiological Interactions, vol. 156, no. 2-3, pp. 131-140, 2005.

[178] D. E. Stevenson, E. F. Walborg Jr., D. W. North et al., "Monograph: reassessment of human cancer risk of aldrin/dieldrin," Toxicology Letters, vol. 109, no. 3, pp. 123-186, 1999.

[179] S. Bachowski, Y. Xu, D. E. Stevenson, E. F. Walborg Jr., and J. E. Klaunig, "Role of oxidative stress in the selective toxicity of dieldrin in the mouse liver," Toxicology and Applied Pharmacology, vol. 150, no. 2, pp. 301-309, 1998.

[180] D. E. Stevenson, J. P. Kehrer, K. L. Kolaja, E. F. Walborg Jr., and J. E. Klaunig, "Effect of dietary antioxidants on dieldrin-induced hepatotoxicity in mice," Toxicology Letters, vol. 75, no. 1-3, pp. 177-183, 1995.

[181] J. E. Klaunig, Y. Xu, S. Bachowski et al., "Oxidative stress in nongenotoxic carcinogenesis," Toxicology Letters, vol. 82-83, pp. 683-691, 1995.

[182] S. J. Stohs, "Oxidative stress induced by 2,3,7,8-tetrachlorodibenzo-p-dioxin (TCDD)," Free Radical Biology and Medicine, vol. 9, no. 1, pp. 79-90, 1990.
[183] N. Z. Alsharif and E. A. Hassoun, "Protective effects of vitamin A and vitamin E succinate against 2,3,7,8-tetrachlorodibenzo-pdioxin (TCDD)-induced body wasting, hepatomegaly, thymic atrophy, production of reactive oxygen species and DNA damage in C57BL/6J mice," Basic and Clinical Pharmacology and Toxicology, vol. 95, no. 3, pp. 131-138, 2004.

[184] S. Wen, F. Yang, Y. Gong et al., "Elevated levels of urinary 8hydroxy-2/-deoxyguanosine in male electrical and electronic equipment dismantling workers exposed to high concentrations of polychlorinated dibenzo- $p$-dioxins and dibenzofurans, polybrominated diphenyl ethers, and polychlorinated biphenyls," Environmental Science and Technology, vol. 42, no. 11, pp. 42024207, 2008

[185] Y. Song, B. A. Wagner, H. J. Lehmler, and G. R. Buettner, "Semiquinone radicals from oxygenated polychlorinated biphenyls: electron paramagnetic resonance studies," Chemical Research in Toxicology, vol. 21, no. 7, pp. 1359-1367, 2008.

[186] K. Shimizu, F. Ogawa, J. J. Thiele, S. Bae, and S. Sato, "Lipid peroxidation is enhanced in Yusho victims 35 years after accidental poisoning with polychlorinated biphenyls in Nagasaki, Japan," Journal of Applied Toxicology, vol. 27, no. 2, pp. 195-197, 2007.

[187] K. Shimizu, F. Ogawa, and S. Sato, "Estimation of total antioxidant power in the serum of Yusho victims," Fukuoka Igaku Zasshi, vol. 98, no. 5, pp. 141-142, 2007.

[188] S. Banudevi, G. Krishnamoorthy, P. Venkataraman, C. Vignesh, M. M. Aruldhas, and J. Arunakaran, "Role of $\alpha$-tocopherol on antioxidant status in liver, lung and kidney of PCB exposed male albino rats," Food and Chemical Toxicology, vol. 44, no. 12, pp. 2040-2046, 2006

[189] G. Krishnamoorthy, P. Venkataraman, A. Arunkumar, R. C. Vignesh, M. M. Aruldhas, and J. Arunakaran, "Ameliorative effect of vitamins ( $\alpha$-tocopherol and ascorbic acid) on PCB (Aroclor 1254) induced oxidative stress in rat epididymal sperm," Reproductive Toxicology, vol. 23, no. 2, pp. 239-245, 2007.

[190] C. Zhou and C. Zhang, "Protective effects of antioxidant vitamins on Aroclor 1254-induced toxicity in cultured chicken embryo hepatocytes," Toxicology in Vitro, vol. 19, no. 5, pp. 665673, 2005.

[191] P. Venkataraman, G. Krishnamoorthy, G. Vengatesh, N. Srinivasan, M. M. Aruldhas, and J. Arunakaran, "Protective role of melatonin on PCB (Aroclor 1254) induced oxidative stress and changes in acetylcholine esterase and membrane bound ATPases in cerebellum, cerebral cortex and hippocampus of adult rat brain," International Journal of Developmental Neuroscience, vol. 26, no. 6, pp. 585-591, 2008.

[192] P. Elumalai, G. Krishnamoorthy, K. Selvakumar, R. Arunkumar, P. Venkataraman, and J. Arunakaran, "Studies on the protective role of lycopene against polychlorinated biphenyls (Aroclor 1254)-induced changes in StAR protein and cytochrome P450 scc enzyme expression on Leydig cells of adult rats," Reproductive Toxicology, vol. 27, no. 1, pp. 41-45, 2009.

[193] J. R. Chang and D. Q. Xu, "Effects of formaldehyde on the activity of superoxide dismutases and glutathione peroxidase and the concentration of malondialdehyde," Wei Sheng Yan Jiu, vol. 35, no. 5, pp. 653-655, 2006.

[194] E. Köse, M. Sarsılmaz, U. Taş et al., "Rose oil inhalation protects against formaldehyde-induced testicular damage in rats," Andrologia, vol. 44, supplement 1, pp. 342-348, 2011.

[195] I. Zararsiz, S. Meydan, M. Sarsilmaz, A. Songur, O. A. Ozen, and S. Sogut, "Protective effects of omega-3 essential fatty acids 
against formaldehyde-induced cerebellar damage in rats," Toxicology and Industrial Health, vol. 27, no. 6, pp. 489-495, 2011.

[196] I. Zararsiz, M. Sarsilmaz, U. Tas, I. Kus, S. Meydan, and E. Ozan, "Protective effect of melatonin against formaldehyde-induced kidney damage in rats," Toxicology and Industrial Health, vol. 23, no. 10, pp. 573-579, 2007.

[197] J. A. Brent and B. H. Rumack, "Role of free radicals in toxic hepatic injury. II. Are free radicals the cause of toxin-induced liver injury?" Journal of Toxicology: Clinical Toxicology, vol. 31, no. 1, pp. 173-196, 1993.

[198] C. Tsai, Y. Hsu, W. Chen et al., "Hepatoprotective effect of electrolyzed reduced water against carbon tetrachloride-induced liver damage in mice," Food and Chemical Toxicology, vol. 47, no. 8, pp. 2031-2036, 2009.

[199] J. D. Morrow, J. A. Awad, T. Kato et al., "Formation of novel non-cyclooxygenase-derived prostanoids (F2-lsoprostanes) in carbon tetrachloride hepatotoxicity: an animal model of lipid peroxidation," Journal of Clinical Investigation, vol. 90, no. 6, pp. 2502-2507, 1992.

[200] S. Basu, "Carbon tetrachloride-induced lipid peroxidation: eicosanoid formation and their regulation by antioxidant nutrients," Toxicology, vol. 189, no. 1-2, pp. 113-127, 2003.

[201] F. Ozturk, M. Gul, B. Ates et al., "Protective effect of apricot (Prunus armeniaca L.) on hepatic steatosis and damage induced by carbon tetrachloride in Wistar rats," British Journal of Nutrition, vol. 102, no. 12, pp. 1767-1775, 2009.

[202] O. A. Adaramoye, "Comparative effects of vitamin E and kolaviron (a biflavonoid from Garcinia kola) on carbon tetrachlorideinduced renal oxidative damage in mice," Pakistan Journal of Biological Sciences, vol. 12, no. 16, pp. 1146-1151, 2009.

[203] Y. W. Hsu, C. F. Tsai, W. C. Chuang, W. K. Chen, Y. C. Ho, and F. J. Lu, "Protective effects of silica hydride against carbon tetrachloride-induced hepatotoxicity in mice," Food and Chemical Toxicology, vol. 48, no. 6, pp. 1644-1653, 2010.

[204] E. R. Sindhu, A. P. Firdous, K. C. Preethi, and R. Kuttan, "Carotenoid lutein protects rats from paracetamol-, carbon tetrachloride- and ethanol-induced hepatic damage," Journal of Pharmacy and Pharmacology, vol. 62, no. 8, pp. 1054-1060, 2010.

[205] H. Lee, L. Li, H. Kim et al., "The protective effects of Curcuma longa Linn. extract on carbon tetrachloride-induced hepatotoxicity in rats via upregulation of Nrf2," Journal of Microbiology and Biotechnology, vol. 20, no. 9, pp. 1331-1338, 2010.

[206] T. Annadurai, S. Vigneshwari, R. Thirukumaran, P. A. Thomas, and P. Geraldine, "Acetyl-L-carnitine prevents carbon tetrachloride-induced oxidative stress in various tissues of Wistar rats," Journal of Physiology and Biochemistry, vol. 67, no. 4, pp. 519-530, 2011.

[207] B. O. Cho, H. W. Ryu, C. H. Jin et al., "Blackberry extract attenuates oxidative stress through up-regulation of Nrf2dependent antioxidant enzymes in carbon tetrachloride-treated rats," Journal of Agricultural and Food Chemistry, vol. 59, no. 21, pp. 11442-11448, 2011.

[208] M. H. Hassan, M. Edfaway, A. Mansour, and A. A. Hamed, "Antioxidant and antiapoptotic effects of capsaicin against carbon tetrachloride-induced hepatotoxicity in rats," Toxicology and Industrial Health, vol. 28, no. 5, pp. 428-438, 2012.

[209] M. Bhadauria, "Propolis prevents hepatorenal injury induced by chronic exposure to carbon tetrachloride," Evidence-Based Complementary and Alternative Medicine, vol. 2012, Article ID 235358, 12 pages, 2012.
[210] M. Aranda, C. D. Albendea, F. Lostalé et al., "In vivo hepatic oxidative stress because of carbon tetrachloride toxicity: protection by melatonin and pinoline," Journal of Pineal Research, vol. 49, no. 1, pp. 78-85, 2010.

[211] K. S. Almurshed, "Protective effect of black and green tea against carbon tetrachloride-induced oxidative stress in rats," Saudi Medical Journal, vol. 27, no. 12, pp. 1804-1809, 2006.

[212] E. A. Hassoun and S. Ray, "The induction of oxidative stress and cellular death by the drinking water disinfection byproducts, dichloroacetate and trichloroacetate in J774.A1 cells," Comparative Biochemistry and Physiology C: Toxicology and Pharmacology, vol. 135, no. 2, pp. 119-128, 2003.

[213] A. K. Yadav, A. Bracher, S. F. Doran et al., "Mechanisms and modification of chlorine-induced lung injury in animals," Proceedings of the American Thoracic Society, vol. 7, no. 4, pp. 278-283, 2010.

[214] M. Leustik, S. Doran, A. Bracher et al., "Mitigation of chlorineinduced lung injury by low-molecular-weight antioxidants," American Journal of Physiology: Lung Cellular and Molecular Physiology, vol. 295, no. 5, pp. L733-L743, 2008.

[215] S. G. Zarogiannis, A. Jurkuvenaite, S. Fernandez et al., "Ascorbate and deferoxamine administration after chlorine exposure decrease mortality and lung injury in mice," American Journal of Respiratory Cell and Molecular Biology, vol. 45, no. 2, pp. 386392, 2011.

[216] Y. Kawai, Y. Matsui, H. Kondo et al., "Galloylated catechins as potent inhibitors of hypochlorous acid-induced DNA damage," Chemical Research in Toxicology, vol. 21, no. 7, pp. 1407-1414, 2008.

[217] D. Tan, L. C. Manchester, R. J. Reiter, W. Qi, M. Karbownik, and J. R. Calvo, "Significance of melatonin in antioxidative defense system: Reactions and products," Biological Signals and Receptors, vol. 9, no. 3-4, pp. 137-159, 2000.

[218] O. N. Medina-Campos, D. Barrera, S. Segoviano-Murillo et al., "S-allylcysteine scavenges singlet oxygen and hypochlorous acid and protects LLC-PK1 cells of potassium dichromateinduced toxicity," Food and Chemical Toxicology, vol. 45, no. 10, pp. 2030-2039, 2007.

[219] R. Argüello-García, O. N. Medina-Campos, N. PérezHernández, J. Pedraza-Chaverrí, and G. Ortega-Pierres, "Hypochlorous acid scavenging activities of thioallyl compounds from garlic," Journal of Agricultural and Food Chemistry, vol. 58, no. 21, pp. 11226-11233, 2010.

[220] M. Strosova, J. Karlovska, C. M. Spickett, T. Grune, Z. Orszagova, and L. Horakova, "Oxidative injury induced by hypochlorous acid to Ca-ATPase from sarcoplasmic reticulum of skeletal muscle and protective effect of trolox," General Physiology and Biophysics, vol. 28, no. 2, pp. 195-209, 2009.

[221] A. C. Carr, T. Tijerina, and B. Frei, "Vitamin C protects against and reverses specific hypochlorons acid- and chloraminedependent modifications of low-density lipoprotein," Biochemical Journal, vol. 346, part 2, pp. 491-499, 2000.

[222] B. M. Rezk, G. R. M. M. Haenen, W. J. F. van der Vijgh, and A. Bast, "Lipoic Acid Protects Efficiently only against a Specific Form of Peroxynitrite-induced Damage," Journal of Biological Chemistry, vol. 279, no. 11, pp. 9693-9697, 2004.

[223] S. Schaffer, G. P. Eckert, W. E. Müller et al., "Hypochlorous acid scavenging properties of local Mediterranean plant foods," Lipids, vol. 39, no. 12, pp. 1239-1247, 2004.

[224] H. Y. Peng, Y. C. Chu, S. J. Chen, and S. T. Chou, "Hepatoprotection of chlorella against carbon tetrachloride-induced oxidative damage in rats," In Vivo, vol. 23, no. 5, pp. 747-754, 2009. 
[225] K. Jomova and M. Valko, "Advances in metal-induced oxidative stress and human disease," Toxicology, vol. 283, no. 2-3, pp. 6587, 2011.

[226] M. Oliva, J. J. Vicente, C. Gravato, L. Guilhermino, and M. L. Galindo-Riaño, "Oxidative stress biomarkers in Senegal sole, Solea senegalensis, to assess the impact of heavy metal pollution in a Huelva estuary (SW Spain): seasonal and spatial variation," Ecotoxicology and Environmental Safety, vol. 75, no. 1, pp. 151162, 2012.

[227] U. J. Yang, T. S. Park, and S. M. Shim, "Protective effect of chlorophyllin and lycopene from water spinach extract on cytotoxicity and oxidative stress induced by heavy metals in human hepatoma cells," Journal of Toxicology and Environmental Health A, vol. 76, no. 23, pp. 1307-1315, 2013.

[228] H. Xing, S. Li, Z. Wang, X. Gao, S. Xu, and X. Wang, "Oxidative stress response and histopathological changes due to atrazine and chlorpyrifos exposure in common carp," Pesticide Biochemistry and Physiology, vol. 103, no. 1, pp. 74-80, 2012.

[229] S. Eroğlu, D. Pandir, F. G. Uzun, and H. Bas, "Protective role of vitamins $\mathrm{C}$ and $\mathrm{E}$ in diclorvos-induced oxidative stress in human erythrocytes in vitro," Biological Research, vol. 46, no. 1, pp. 33-38, 2013.

[230] R. Demirel, H. Mollaoğlu, Y. Yeşilyurt et al., "Noise induces oxidative stress in rat," European Journal of General Medicine, vol. 6, no. 1, pp. 20-24, 2009.

[231] D. Henderson, E. C. Bielefeld, K. C. Harris, and B. H. Hu, "The role of oxidative stress in noise-induced hearing loss," Ear and Hearing, vol. 27, no. 1, pp. 1-19, 2006.

[232] S. Manikandan and R. S. Devi, "Antioxidant property of $\alpha$-asarone against noise-stress-induced changes in different regions of rat brain," Pharmacological Research, vol. 52, no. 6, pp. 467-474, 2005.

[233] S. Manikandan, R. Srikumar, N. J. Parthasarathy, and R. S. Devi, "Protective effect of Acorus calamus Linn on free radical scavengers and lipid peroxidation in discrete regions of brain against noise stress exposed rat," Biological \& Pharmaceutical Bulletin, vol. 28, no. 12, pp. 2327-2330, 2005.

[234] F. Ozguner, A. Altinbas, M. Ozaydin et al., "Mobile phoneinduced myocardial oxidative stress: protection by a novel antioxidant agent caffeic acid phenethyl ester," Toxicology and Industrial Health, vol. 21, no. 9, pp. 223-230, 2005.

[235] L. E. van Campen, W. J. Murphy, J. R. Franks, P. I. Mathias, and M. A. Toraason, "Oxidative DNA damage is associated with intense noise exposure in the rat," Hearing Research, vol. 164, no. 1-2, pp. 29-38, 2002.

[236] G. Lorito, P. Giordano, S. Prosser, A. Martini, and S. Hatzopoulos, "Noise-induced hearing loss: a study on the pharmacological protection in the Sprague Dawley rat with $\mathrm{N}$-acetylcysteine," Acta Otorhinolaryngologica Italica, vol. 26, no. 3, pp. 133-139, 2006.

[237] D. L. Ewert, J. Lu, W. Li, X. Du, R. Floyd, and R. Kopke, "Antioxidant treatment reduces blast-induced cochlear damage and hearing loss," Hearing Research, vol. 285, no. 1-2, pp. 29-39, 2012.

[238] O. W. Guthrie, "Dynamic compartmentalization of DNA repair proteins within spiral ganglion neurons in response to noise stress," International Journal of Neuroscience, vol. 122, no. 12, pp. 757-766, 2012.

[239] L. D. Fechter, "Oxidative stress: a potential basis for potentiation of noise-induced hearing loss," Environmental Toxicology and Pharmacology, vol. 19, no. 3, pp. 543-546, 2005.
[240] J. D. Hackney, W. S. Linn, R. D. Buckley et al., "Vitamin E supplementation and respiratory effects of ozone in humans," Journal of Toxicology and Environmental Health, vol. 7, no. 3-4, pp. 383-390, 1981.

[241] A. Ruano-Ravina, A. Figueiras, M. Freire-Garabal, and J. M. Barros-Dios, "Antioxidant vitamins and risk of lung cancer," Current Pharmaceutical Design, vol. 12, no. 5, pp. 599-613, 2006.

[242] D. Albanes, "Beta-carotene and lung cancer: a case study," The American Journal of Clinical Nutrition, vol. 69, no. 6, pp. 1345S1350S, 1999.

[243] M. L. Neuhouser, R. E. Patterson, M. D. Thornquist, G. S. Omenn, I. B. King, and G. E. Goodman, "Fruits and vegetables are associated with lower lung cancer risk only in the placebo arm of the $\beta$-Carotene and Retinol Efficacy Trial (CARET)," Cancer Epidemiology Biomarkers and Prevention, vol. 12, no. 4, pp. 350-358, 2003.

[244] Y. G. J. van Helden, J. Keijer, A. M. Knaapen et al., "Betacarotene metabolites enhance inflammation-induced oxidative DNA damage in lung epithelial cells," Free Radical Biology and Medicine, vol. 46, no. 2, pp. 299-304, 2009.

[245] F. McArdle, L. E. Rhodes, R. A. G. Parslew et al., "Effects of oral vitamin $\mathrm{E}$ and $\beta$-carotene supplementation on ultraviolet radiation-induced oxidative stress in human skin," American Journal of Clinical Nutrition, vol. 80, no. 5, pp. 1270-1275, 2004.

[246] C. Wolf, A. Steiner, and H. Honingsmann, "Do oral carotenoids protect human skin against ultraviolet erythema, psoralen phototoxicity, and ultraviolet-induced DNA-damage?" Journal of Investigative Dermatology, vol. 90, no. 1, pp. 55-57, 1988.

[247] M. Garmyn, J. D. Ribaya-Mercado, R. M. Russel, J. Bhawan, and B. A. Gilchrest, "Effect of beta-carotene supplementation on the human sunburn reaction," Experimental Dermatology, vol. 4, no. 2, pp. 104-111, 1995.

[248] P. Korbashi, R. Kohen, J. Katzhendler, and M. Chevion, "Iron mediates paraquat toxicity in Escherichia coli," The Journal of Biological Chemistry, vol. 261, no. 27, pp. 12472-12476, 1986.

[249] R. Kohen and M. Chevion, "Transition metals potentiate paraquat toxicity.", Free radical research communications, vol. 1, no. 2, pp. 79-88, 1985.

[250] C. Latchoumycandane and P. P. Mathur, "Effects of vitamin E on reactive oxygen species-mediated 2,3,7,8-tetrachlorodibenzo-pdioxin toxicity in rats testis," Journal of Applied Toxicology, vol. 22, no. 5, pp. 345-351, 2002.

[251] A. Furukawa, S. Oikawa, M. Murata, Y. Hiraku, and S. Kawanishi, "(-)-Epigallocatechin gallate causes oxidative damage to isolated and cellular DNA," Biochemical Pharmacology, vol. 66, no. 9, pp. 1769-1778, 2003.

[252] K. Sakano, S. Oikawa, Y. Hiraku, and S. Kawanishi, "Oxidative DNA damage induced by a melatonin metabolite, 6hydroxymelatonin, via a unique non-o-quinone type of redox cycle," Biochemical Pharmacology, vol. 68, no. 9, pp. 1869-1878, 2004.

[253] B. Poljsak, D. Šuput, and I. Milisav, "Achieving the balance between ROS and antioxidants: when to use the synthetic antioxidants," Oxidative Medicine and Cellular Longevity, vol. 2013, Article ID 956792, 11 pages, 2013.

[254] B. Poljsak and I. Milisav, "The neglected significance of 'antioxidative stress"' Oxidative Medicine and Cellular Longevity, vol. 2012, Article ID 480895, 12 pages, 2012.

[255] S. Verhaegn, J. Adrain, J. McGovan, A. R. Brophy, R. S. Fernandes, and T. G. Gotler, "Inhibition of apoptosis by antioxidants in the human IIL-60 leukemia cell line," Biochemical Pharmacology, vol. 40, pp. 1021-1029, 1995. 
[256] R. I. Salganik, “The benefits and hazards of antioxidants: controlling apoptosis and other protective mechanisms in cancer patients and the human population," The Journal of the American College of Nutrition, vol. 20, supplement 5, pp. 464S472S, 2001.

[257] I. D. Podmore, H. R. Griffiths, K. E. Herbert, N. Mistry, P. Mistry, and J. Lunec, "Vitamin C exhibits pro-oxidant properties," Nature, vol. 392, no. 6676, p. 559, 1998.

[258] P. Palozza, "Prooxidant actions of carotenoids in biologic systems," Nutrition Reviews, vol. 56, no. 9, pp. 257-265, 1998.

[259] G. S. Omenn, G. E. Goodman, M. D. Thornquist et al., "Effects of a combination of beta carotene and vitamin A on lung cancer and cardiovascular disease," The New England Journal of Medicine, vol. 334, no. 18, pp. 1150-1155, 1996.

[260] G. Bjelakovic, D. Nikolova, R. G. Simonetti, and C. Gluud, "Antioxidant supplements for prevention of gastrointestinal cancers: a systematic review and meta-analysis," The Lancet, vol. 364, no. 9441, pp. 1219-1228, 2004.

[261] E. R. Miller III, R. Pastor-Barriuso, D. Dalal, R. A. Riemersma, L. J. Appel, and E. Guallar, "Meta-analysis: high-dosage vitamin E supplementation may increase all-cause mortality," Annals of Internal Medicine, vol. 142, no. 1, pp. 37-46, 2005.

[262] R. G. Cutler and M. P. Mattson, "Measuring oxidative stress and interpreting its relevance in humans," in Oxidative Stress and Aging, R. G. Cutler and H. Rodriguez, Eds., World Scientific, River Edge, NJ, USA, 2003.

[263] R. G. Cutler, "Genetic stability, dysdifferentiation, and longevity determinant genes," in Critical Reviews of Oxidative Stress and Damage, R. G. Cutler and H. Rodriguez, Eds., World Scientific, River Edge, NJ, USA, 2003.

[264] D. W. Filho, S. Á. Júnior, F. P. Possamai et al., "Antioxidant therapy attenuates oxidative stress in the blood of subjects exposed to occupational airborne contamination from coal mining extraction and incineration of hospital residues," Ecotoxicology, vol. 19, no. 7, pp. 1193-1200, 2010.

[265] A. Cherubini, G. B. Vigna, G. Zuliani, C. Ruggiero, U. Senin, and R. Fellin, "Role of antioxidants in atherosclerosis: epidemiological and clinical update," Current Pharmaceutical Design, vol. 11, no. 16, pp. 2017-2032, 2005.

[266] S. B. Lotito and B. Frei, "Consumption of flavonoid-rich foods and increased plasma antioxidant capacity in humans: cause, consequence, or epiphenomenon?” Free Radical Biology \& Medicine, vol. 41, no. 12, pp. 1727-1746, 2006. 


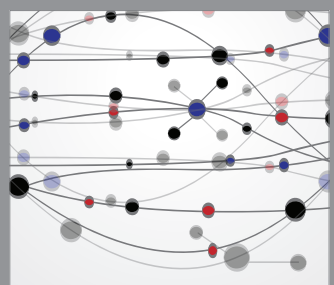

The Scientific World Journal
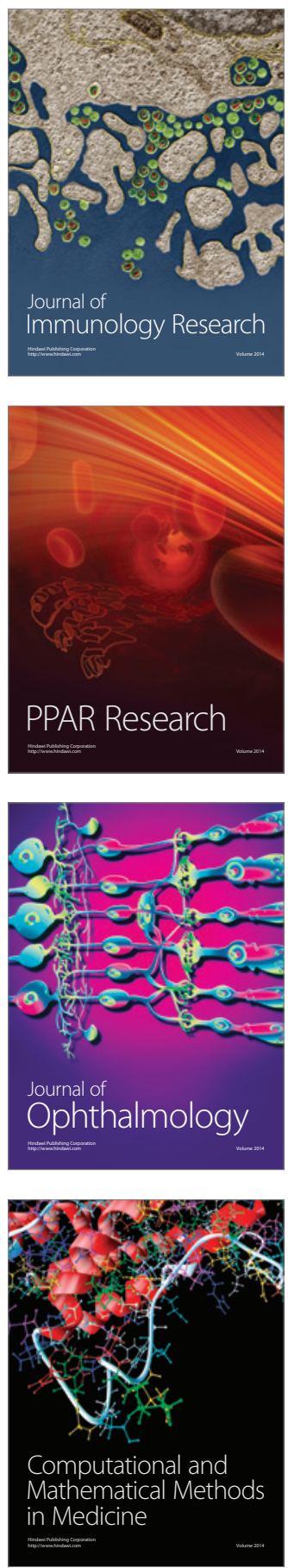

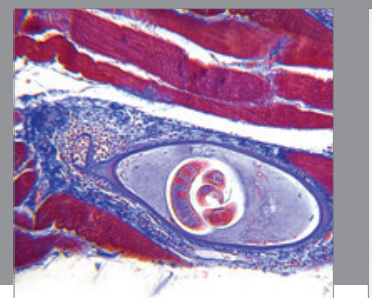

Gastroenterology

Research and Practice
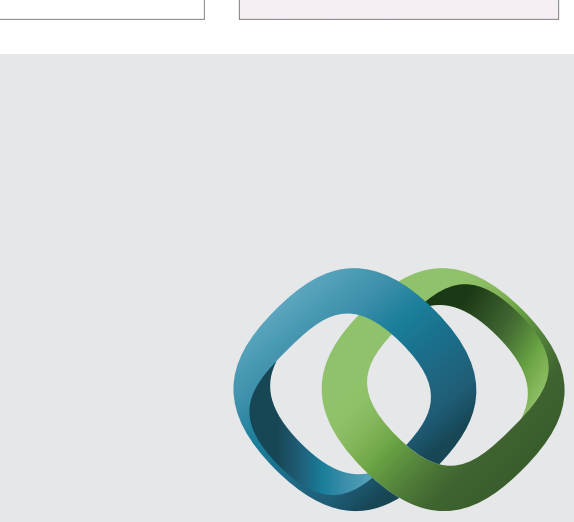

\section{Hindawi}

Submit your manuscripts at

http://www.hindawi.com
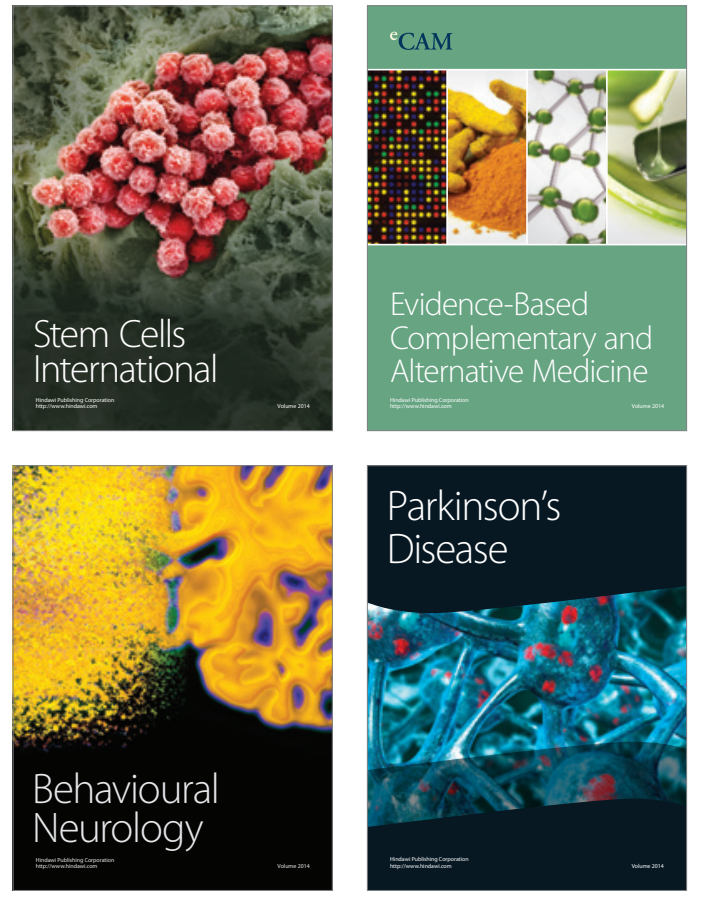
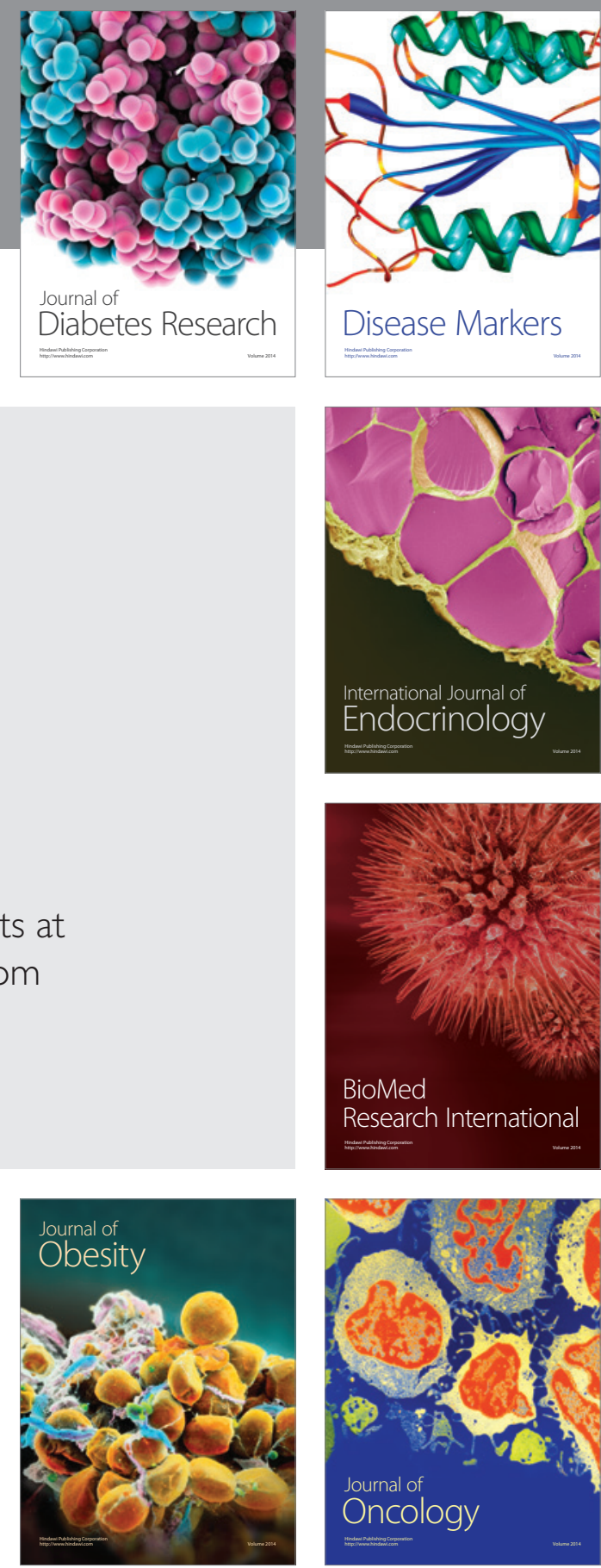

Disease Markers
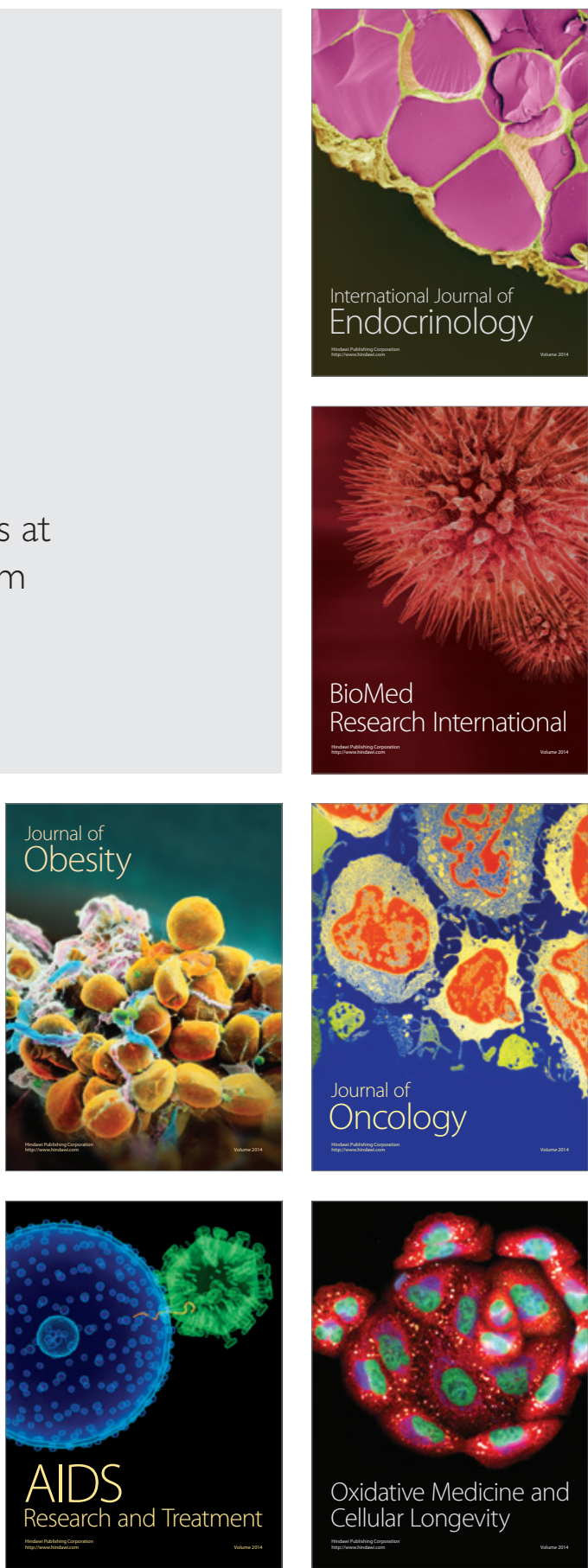